\title{
Beneficial Role of Antioxidant Secondary Metabolites from Medicinal Plants in Maintaining Oral Health
}

\author{
Manoj Kumar 1,*(D), Suraj Prakash ${ }^{2}$ D , Radha ${ }^{2, *}$, Neeraj Kumari ${ }^{2}\left(\mathbb{D}\right.$, Ashok Pundir ${ }^{3}$, Sneh Punia ${ }^{4}$, \\ Vivek Saurabh ${ }^{5}$ (D), Poonam Choudhary ${ }^{6}$, Sushil Changan ${ }^{7}$, Sangram Dhumal ${ }^{8}$, Prakash Chandra Pradhan ${ }^{9}$, \\ Omar Alajil ${ }^{5,10}{ }^{\mathbb{D}}$, Sudha Singh ${ }^{11}$, Neha Sharma ${ }^{12}$, Tamilselvan Ilakiya ${ }^{13} \mathbb{D}$, Surinder Singh ${ }^{14} \mathbb{D}$ and \\ Mohamed Mekhemar $15, *$ (i)
}

1 Chemical and Biochemical Processing Division, ICAR - Central Institute for Research on Cotton Technology, Mumbai 400019, India

2 School of Biological and Environmental Sciences, Shoolini University of Biotechnology and Management Sciences, Solan 173229, India; surajpandiar75@gmail.com (S.P.); neeruguleria1532001@gmail.com (N.K.)

3 School of Mechanical and Civil Engineering, Shoolini University of Biotechnology and Management Sciences, Solan 173229, India; ashok.pundir78791@gmail.com

4 Department of Food, Nutrition, \& Packaging Sciences, Clemson University, Clemson, SC 29634, USA; snehpunia69@gmail.com

5 Division of Food Science and Postharvest Technology, ICAR-Indian Agricultural Research Institute, New Delhi 110012, India; vivek_11593@iari.res.in (V.S.); omar8alajil@gmail.com (O.A.)

Citation: Kumar, M.; Prakash, S.; Radha; Kumari, N.; Pundir, A.; Punia, S.; Saurabh, V.; Choudhary, P.; Changan, S.; Dhumal, S.; et al. Beneficial Role of Antioxidant Secondary Metabolites from Medicinal Plants in Maintaining Oral Health. Antioxidants 2021, 10, 1061. https://doi.org/10.3390/ antiox10071061

Academic Editors: Luca Sebastiani and Filomena Nazzaro

Received: 31 May 2021

Accepted: 25 June 2021

Published: 30 June 2021

Publisher's Note: MDPI stays neutral with regard to jurisdictional claims in published maps and institutional affiliations.

Copyright: (c) 2021 by the authors. Licensee MDPI, Basel, Switzerland. This article is an open access article distributed under the terms and conditions of the Creative Commons Attribution (CC BY) license (https:// creativecommons.org/licenses/by/ $4.0 /)$.
6 Agricultural Structure and Environment Control, ICAR-Central Institute of Post-Harvest Engineering and Technology, Ludhiana 141004, India; poonam@icar.gov.in

7 Division of Crop Physiology, Biochemistry and Post-Harvest Technology, ICAR—Central Potato Research Institute, Shimla 171001, India; sushil.changan@icar.gov.in

8 Division of Horticulture, RCSM College of Agriculture, Kolhapur 416004, India; sdhumal@msu.edu

9 Division of Agricultural Chemicals, ICAR-Indian Agricultural Research Institute, New Delhi 110012, India; prakash0844@gmail.com

10 Department of Food Sciences, Faculty of Agriculture, Aleppo University, Aleppo 15310, Syria

11 Department of Vegetable Science, Dr. Y. S. Parmar University of Horticulture and Forestry, Nauni 173230, India; sudhasingh230795@gmail.com

12 Department of Biotechnology, Dr. Y. S. Parmar University of Horticulture and Forestry, Nauni 173230, India; neha.nea.sharma@gmail.com

13 Department of Vegetable Science, Tamil Nadu Agricultural University, Coimbatore 641003, India; ilakiyatamil@gmail.com

14 Dr. S. S. Bhatnagar University Institute of Chemical Engineering and Technology, Panjab University, Chandigarh 160014, India; ssbhinder@pu.ac.in

15 Clinic for Conservative Dentistry and Periodontology, School of Dental Medicine, Christian-Albrecht's University, 24105 Kiel, Germany

* Correspondence: manoj.kumar13@icar.gov.in (M.K.); radhuchauhan7002@gmail.com (R.); mekhemar@konspar.uni-kiel.de (M.M.)

Abstract: Plant-derived phytochemicals have been touted as viable substitutes in a variety of diseases. All over the world, dentists have turned to natural remedies for dental cure due to the negative possessions of certain antibacterial mediators used in dentistry. Antimicrobial and other drugs are currently in use, but they show some side effects. Since ancient times, antioxidant EOs have been used for different ailments and have grown in popularity over time. Several in vitro, in vivo, and clinical trials have shown the safety and effectiveness of antioxidant essential oils (EOs) in oral health obtained from medicinal plants. The current review of literature provides a summary of secondary metabolites, more specifically EOs from 20 most commonly used medicinal plants and their applications in maintaining oral health. Dental caries and periodontal diseases are the most common and preventable global infectious diseases, with diseases of the oral cavity being considered major diseases affecting a person's health. Several clinical studies have shown a connection between oral diseases and oral microbiota. This review discusses the role of antioxidant secondary metabolites in inhibiting the growth of oral pathogens and reducing the formation of dental plaque, and as well as reducing the symptoms of oral diseases. This review article contributes a basic outline of essential oils and their healing actions. 
Keywords: phytochemicals; oral health; essential oils; medicinal plants

\section{Introduction}

Oral diseases are the main worldwide health complications that affect approximately 3.5 billion people worldwide due to their chronic and progressive nature. Most oral diseases can be treated in their early stages and are largely preventable. With the increasing urbanization and changes in lifestyle, mostly in developing countries prevalence of oral diseases continues to increase. The poor access to oral health care facilities in the community, having food and beverages high in sugar, and insufficient exposure to fluoride in toothpaste or water supply will be the reasons behind the increase in oral disease. The most common oral diseases that include clinical conditions affecting mouth and teeth are periodontal (gum) diseases, dental caries (tooth decay), oral cancers, oro-dental trauma, oral manifestations of HIV, cleft lip and palate, and Noma. It was reported in earlier studies that approximately 2.3 billion people suffer from dental caries of permanent teeth [1]. In earlier studies, it was reported that approximately $20 \%$ of people suffer from oral diseases [2]. The cure is lengthy and costly, which consequently results in complications for psychological and facial growth.

Having maximum efficiency and minimum harmful effects, the natural products derived from medicinal plants play a vital role in oral health complications such as bleeding gums, mouth ulcers, dental caries, gingivitis, and halitosis. The different plant species produce different kinds of secondary metabolites. According to a study, approximately $30 \%$ of entire plant species were used for medicinal purposes depending on the type and amount of secondary metabolite they contain [3]. In developing countries, drugs of plant origin have a significant role in saving the life of many peoples. Despite the advances in synthetic drugs and modern medicine still, a large sector of world residents has a dependence on plant-origin drugs [3]. According to WHO, most of the global population has a dependency on medicinal plants as health care requirements. Drugs including amine fluorides, chlorhexidine, cetylpyridinium chloride, and triclosan were commonly used in dental care products, cause staining of teeth, and are toxic if used in excess [4]. Mouthwashes made from natural products are found to be useful in the treatment of gingivitis and plaque with effective antimicrobial activity. In odontology, herbal extracts from medicinal plants were used as antimicrobial plaque agents, antioxidants, analgesics, and antivirals to prevent histamine release because of fewer side effects and low toxicity [4]. In recent years, herbal plant extract of neem leaf, burdock root, propolis, and noni fruit were used as intra-canal medications and, having effective results, provided a novel function in global dental therapy for herbal agents [5].

At the present time, there is an upsurge in demand for essential oils extracted from various medicinal plants in the pharmacological industry due to their antioxidant, antifungal, antimicrobial and antiviral properties. EOs contain a mixture of chemical composites having less molecular weight, such as terpenoids, carbonyl compounds, alcohols, aliphatic compounds, and polyphenols [6-8]. In recent time approximately 3000 EOs has been reported [9]. As compared to synthetic chemicals, essential oils (natural) were harmless for the atmosphere and are more effective. The essential oils were taken out from different plant parts with leaves, fruits, flowers, bark, and root by using steam distillation, solvent extraction, and hydrodistillation. The essential oil of Zanthoxylum armatum is commonly called Zanthoxylum oil and is known to treat inflammatory pain of toothache. In the pharmaceutical industry, fruit extract is used as an ingredient in toothpaste due to its antioxidant and antimicrobial properties. Ocimum sanctum, the sacred plant commonly called tulsi, is used for medicinal purposes. The essential oil of Ocimum sanctum possesses antimicrobial, antifungal properties against oral pathogens known to cause dental problems and is used as an ingredient in mouthwash, toothpaste by pharmaceutical industries to treat toothache and pupiltis. Eugenol, one of the extensively used compounds in dentistry, is also present 
in the essential oil extracted from the leaves of tulsi. EO of Salvadora persica (miswak) is used extensively in mouthwash, toothpaste, dental varnish, dental cement due to the bioactive compounds present in it. The essential oil of miswak is reported to have antigingivitis, orthodontic chain preservation, promotion of gingival wound healing, antiplaque, anti-cariogenic, and whitening properties [10]. The essential oil of Eucalyptus globulus, commonly called eucalyptus oil, contains the biologically active compound eucalyptol and is used in dentistry for mouthwash and dental preparations as an endodontic solvent [11]. Thyme oil extracted from Thymus vulgaris reported to have antimicrobial properties and is used as an antiseptic mouth wash, toothpaste, and treatment of oral infection [12].

All over the world, oral infections persist in being a key health issue. It was found that dental caries, oral tissue lesions, and oral cancers are dangerous diseases that are the greatest chief global oral health complications. Oral fitness is very important to overall well-being. In earlier studies, it was found that a strong connection between activities of the microbiota of the oral cavity and oral illnesses. About 750 bacterial species are responsible for oral illnesses [13]. All over the world, there is a requirement for alternative preventative options, treatments, and products for oral illnesses that are safe and highly effective $[14,15]$. This review summarizes existing available data on the subject of medicinal usage, phytochemical composition, and pharmacological properties and evaluates the possible opportunities to use essential oils for oral infections. The EOs are less toxic, and they contain biologically active compounds having medicinal properties due to which in the last few years, there is an increase in demand, especially in pharmacological industries related to dentistry, therefore a systematic review of the phytochemical composition of EOs, and medicinal properties can help the students, researchers, and stakeholders in the development of new products to treat oral health problems such as periodontitis, dental caries (tooth decay), gingivitis. From this time, the search for other possible products continues, and naturally available chemicals extracted from medicinal plants used in traditional medicine are considered as suitable alternatives to commercially available chemicals. The products derived from different medicinal plants such as Azadirachta indica, Thymus vulgaris, Asparagus racemosus, Juglans regia, and Ocimum sanctum possess different types of phytochemicals and some used in pharmaceuticals [16-22]. The medicinal plants discussed in the current review are presented with their systematic classification in Table 1, their role in oral health is given in Table 2, and photographs of few discussed plants are shown in Figure 1. This review presents a comprehensive compilation of traditional medicines or phytochemicals extracts that inhibit the growth of oral pathogens, dental plaque and decrease the warning sign of oral illnesses. Further, the review also explores the information related to antioxidant EOs and their beneficial role in improving oral health. It was observed that very few studies have been available for an oral health cure. 
Table 1. Systematic classification of the medicinal plants discussed in the current review.

\begin{tabular}{|c|c|c|c|c|c|c|c|c|c|}
\hline Sr. No. & Common Name & Kingdom & Phylum & Class & Order & Family & Genus & Species & Binomial Classification \\
\hline 1. & Tejphal & Plantae & Magnoliophyta & Magnoliopsida & Sapindales & Rutaceae & Zanthoxylum & $\begin{array}{l}\text { Zanthoxylum } \\
\text { armatum }\end{array}$ & Zanthoxylum armatum DC. \\
\hline 2. & Tulsi & Plantae & Magnoliophyta & Magnoliopsida & Lamiales & Lamiaceae & Ocimum & Ocimum sanctum & Ocimum sanctum Linn. \\
\hline 4. & Nilgiri & Plantae & Magnoliophyta & Magnoliopsida & Myrtales & Myrtaceae & Eucalyptus & Eucalyptus globulus & Eucalyptus globulus Labill. \\
\hline 5. & Banajwain & Plantae & Magnoliophyta & Magnoliopsida & Lamiales & Lamiaceae & Thymus & Thymus vulgaris & Thymus vulgaris L. \\
\hline 6. & Neem & Plantae & Magnoliophyta & Magnoliopsida & Sapindales & Meliaceae & Azadirachta & Azadirachta indica & Azadirachta indica A. Juss. \\
\hline 8. & Akhrot & Plantae & Magnoliophyta & Magnoliopsida & Juglandales & Juglandaceae & Juglans & Juglans regia & Juglans regia $\mathrm{L}$. \\
\hline 9. & Satavari & Plantae & Magnoliophyta & Liliopsida & Asparagales & Asparagaceae & Asparagus & $\begin{array}{l}\text { Asparagus } \\
\text { racemosus }\end{array}$ & Asparagus racemosus Willd. \\
\hline 10. & Aaraar & Plantae & Coniferophyta & Pinopsida & Pinales & Cupressaceae & Juniperus & $\begin{array}{l}\text { Juniperus } \\
\text { communis }\end{array}$ & Juniperus communis $L$. \\
\hline 11. & Tea tree & Plantae & Magnoliophyta & Magnoliopsida & Myrtales & Myrtaceae & Melaleuca & $\begin{array}{l}\text { Melaleuca } \\
\text { alternifolia }\end{array}$ & $\begin{array}{l}\text { Melaleuca alternifolia (Maiden } \\
\text { and Betche) Cheel }\end{array}$ \\
\hline 12. & Babul & Plantae & Magnoliophyta & Magnoliopsida & Fabales & Fabaceae & Acacia & Acacia nilotica & Acacia nilotica (L.) Delile \\
\hline 14. & Estragon & Plantae & Magnoliophyta & Magnoliopsida & Asterales & Asteraceae & Artemisia & $\begin{array}{l}\text { Artemisia } \\
\text { dracunculus }\end{array}$ & Artemisia dracunculus $\mathrm{L}$. \\
\hline 15. & Khoi & Plantae & Magnoliophyta & Magnoliopsida & Urticales & Moraceae & Streblus & Streblus asper & Streblus asper Lour. \\
\hline 16. & Chicory & Plantae & Magnoliophyta & Magnoliopsida & Asterales & Asteraceae & Cichorium & Cichorium intybus & Cichorium intybus L. \\
\hline 17. & Nirgundi & Plantae & Magnoliophyta & Magnoliopsida & Lamiales & Verbenaceae & Vitex & Vitex negundo & Vitex negundo L. \\
\hline 18. & Rosemary & Plantae & Magnoliophyta & Magnoliopsida & Lamiales & Lamiaceae & Rosmarinus & $\begin{array}{l}\text { Rosmarinus } \\
\text { officinalis }\end{array}$ & Rosmarinus officinalis L. \\
\hline 19. & Vaibidang & Plantae & Magnoliophyta & Magnoliopsida & Ericales & Primulaceae & Embelia & $\begin{array}{l}\text { Embelia ribes } \\
\text { Burm.f. }\end{array}$ & Embelia ribes Burm.f. \\
\hline 20. & Akalkara & Plantae & Magnoliophyta & Magnoliopsida & Asterales & Asteraceae & Spilanthes & Spilanthes acmella & Spilanthes acmella (L.) L. \\
\hline 21. & Kalonji & Plantae & Magnoliophyta & Magnoliopsida & Ranunculales & Ranunculaceae & Nigella & Nigella Sativa & Nigella sativa L. \\
\hline
\end{tabular}


Table 2. Medicinal plants useful in oral health.

\begin{tabular}{|c|c|c|c|c|c|}
\hline $\begin{array}{l}\text { Botanical Name } \\
\text { (Common Name) }\end{array}$ & Location & $\begin{array}{c}\text { Extraction Method or Type of } \\
\text { Solvent }\end{array}$ & Essential Oil Components & $\begin{array}{l}\text { Study Type (In Vitro/In Vivo/Clinical } \\
\text { Trial) and Dose of the Extract }\end{array}$ & Role in Oral Health \\
\hline \multirow{4}{*}{$\begin{array}{l}\text { Zanthoxylum armatum } \\
\text { DC. (Tejphal, Tumbru) }\end{array}$} & \multirow{4}{*}{$\begin{array}{l}\text { India: Kashmir to Bhutan, } \\
\text { China, Taiwan, Malaysia, } \\
\text { Japan [23] }\end{array}$} & \multirow[t]{2}{*}{$\begin{array}{l}\text { Hydrodistillation method, } \\
\text { Analyzed-GC-MS }\end{array}$} & \multirow{4}{*}{$\begin{array}{c}\text { Linalool (53.05\%), Limonene } \\
(11.39 \%), \text { Myrcene }(3.69 \%), \\
\alpha \text {-pinene (4.08\%), Bergamot mint } \\
\text { oil }(12.73 \%)[23]\end{array}$} & $\begin{array}{l}\text { Study-In vitro (antibacterial-) on } \\
\text { Streptococcus faecalis, S. aureus, Proteus } \\
\text { vulgaris, Klebsiella pneumoniae }\end{array}$ & \\
\hline & & & & Dose: $10 \mathrm{mg} /$ well & \\
\hline & & \multirow[b]{2}{*}{$\begin{array}{l}\text { Essential oil extracted from seeds } \\
\text { [23] }\end{array}$} & & Application: Essential oil & \\
\hline & & & & [24] & $\begin{array}{l}\text { Gum bleeding, Mouth Freshener, } \\
\text { Toothache, Toothpowder, Tooth } \\
\text { Cleaning [25] }\end{array}$ \\
\hline \multirow{3}{*}{$\begin{array}{l}\text { Ocimum sanctum Linn. } \\
\text { (Holy Basil, Tulsi) }\end{array}$} & \multirow{3}{*}{$\begin{array}{c}\text { India (Uttar Pradesh) } \\
\text { Andaman and Nicobar, } \\
\text { Africa, South America, } \\
\text { Brazil [26] }\end{array}$} & $\begin{array}{l}\text { Hydrodistillation method, } \\
\text { Analyzed-GC-MS }\end{array}$ & \multirow{3}{*}{$\begin{array}{c}\text { Caryophyllene (22.265\%), } \\
\alpha \text {-caryophyllene }(2.071 \%), \\
\alpha \text {-pinene }(0.125 \%), \text { copaene } \\
(1.637 \%) \text { and eugenol } \\
(15.906 \%)[27]\end{array}$} & $\begin{array}{l}\text { In vivo (clinical trial) on humans for } \\
\text { efficiency of mouth wash containing } \\
\text { tulsi, VAS score for burning } \\
\text { sensation-Pre-treatment }(5.33 \pm 1.80) \\
\text { Post-treatment }(2.44 \pm 2.10)\end{array}$ & Oil extract used to treat toothache \\
\hline & & \multirow{2}{*}{$\begin{array}{l}\text { Essential oil extracted from dried } \\
\text { leaves [27] }\end{array}$} & & Dose: $10 \mathrm{~mL}$ (thrice)/day-one week), & \\
\hline & & & & Application: Mouthwash [28] & $\begin{array}{l}\text { Dried leaves used to treat gingival and } \\
\text { periodontal diseases [29] }\end{array}$ \\
\hline \multirow{2}{*}{$\begin{array}{l}\text { Salvadora persica } \mathrm{L} . \\
\text { (Miswak) }\end{array}$} & \multirow{2}{*}{$\begin{array}{l}\text { India, East, Southern and } \\
\text { North Africa, South and West } \\
\text { Asia, Arabic Peninsula [30] }\end{array}$} & Essential oil extracted from & \multirow{2}{*}{$\begin{array}{c}\alpha \text {-caryophellene (13.4\%), } \\
\text { 1,8-cineole (eucalyptol) }(46 \%), \\
\text { 9-epi. -(E.)-caryophellene, } \\
\beta \text {-pinene (6.3\%) [31] }\end{array}$} & Dose: twice/day (2 weeks) & \multirow{2}{*}{$\begin{array}{l}\text { Antigingivitis, anti-cariogenic, } \\
\text { antiplaque, whitening properties, } \\
\text { orthodontic chain preservation and } \\
\text { promotion of gingival wound } \\
\text { healing [10] }\end{array}$} \\
\hline & & stem [31] & & Application: Toothpaste [32] & \\
\hline \multirow{4}{*}{$\begin{array}{l}\text { Eucalyptus globulus } \\
\text { Labill. (Nilgiri) }\end{array}$} & \multirow{4}{*}{$\begin{array}{l}\text { India: Goa, Gujrat, Haryana, } \\
\text { Punjab, Uttar Pradesh. } \\
\text { Albina, Spain, Uganda, } \\
\text { Cambodia [33] }\end{array}$} & $\begin{array}{l}\text { Analyzed by GC-MS, } \\
\text { (a) }\end{array}$ & \multirow{4}{*}{$\begin{array}{c}\beta \text {-pinene } 18.54 \% \text {, eucalyptol } \\
(1,8 \text {-cineole) } 54.79 \% \text {, para cymene } \\
1.60 \%, \beta \text {-eudesmol } 4.68 \% \text {, } \\
\alpha \text {-phellandrene } 2.06 \%, \alpha \text {-pinene } \\
11.46 \% \text { and gamma-eudesmol } \\
1.20 \%[34]\end{array}$} & In vivo (clinical trial) on humans, & \multirow{4}{*}{$\begin{array}{l}\text { For treatment of toothache, sore throat } \\
\text { halitosis in Cameroon mouthwash } \\
\text { gargle of Eucalyptus saligna is used [3] }\end{array}$} \\
\hline & & $\begin{array}{c}\text { method, essential oil extracted } \\
\text { from leaves [34] }\end{array}$ & & $\begin{array}{c}\text { Plaque index score-Baseline } \\
(1.485 \pm 0.34), \text { After } 14 \text { days } \\
(1.254 \pm 0.58) .\end{array}$ & \\
\hline & & & & Dose: $10 \mathrm{~mL}$ twice/day (14 days) & \\
\hline & & & & Application—Gargle, Mouthwash [35] & \\
\hline
\end{tabular}


Table 2. Cont.

\begin{tabular}{|c|c|c|c|c|c|}
\hline $\begin{array}{l}\text { Botanical Name } \\
\text { (Common Name) }\end{array}$ & Location & $\begin{array}{c}\text { Extraction Method or Type of } \\
\text { Solvent }\end{array}$ & Essential Oil Components & $\begin{array}{c}\text { Study Type (In Vitro/In Vivo/Clinical } \\
\text { Trial) and Dose of the Extract }\end{array}$ & Role in Oral Health \\
\hline \multirow{2}{*}{$\begin{array}{l}\text { Thymus vulgaris } \mathrm{L} \text {. } \\
\text { (Thyme, Banajwain) }\end{array}$} & \multirow{2}{*}{$\begin{array}{c}\text { India (Western Himalayas } \\
\text { and Nilgiris), Spain, } \\
\text { European countries, Svizzera, } \\
\text { France, Italy, Portuguese } \\
\text { Republic, Bulgaria, and } \\
\text { Ellas [36] }\end{array}$} & $\begin{array}{l}\text { Steam distillation method, } \\
\text { Analyzed- GC-MS }\end{array}$ & \multirow{2}{*}{$\begin{array}{c}\text { Thymol }(3.82 \%), \alpha \text {-thymol } \\
(38.71 \%) \text { camphene }(0.13 \%), \\
\text { caryophyllene }(0.915), \text { humulene } \\
(0.22 \%), \alpha \text {-terpineol }(0.285) \text { and } \\
\rho \text {-cymene }(2.77 \%)[20]\end{array}$} & $\begin{array}{l}\text { In vitro antimicrobial effect against } \\
\text { Streptococcus mutans (ATCC 25175), }\end{array}$ & \\
\hline & & $\begin{array}{l}\text { Essential oil extracted from } \\
\text { leaves [20] }\end{array}$ & & Application: Mouthwash [37] & $\begin{array}{l}\text { Used in toothpaste, mouth rinse, and } \\
\text { aromatherapy for prevention and } \\
\text { treatment of oral infection }[12,38]\end{array}$ \\
\hline \multirow{4}{*}{ Azadirachta indica (Neem) } & \multirow{4}{*}{$\begin{array}{l}\text { Afghanistan, Pakistan, India, } \\
\text { Sri Lanka, Bangladesh, } \\
\text { Myanmar, and China [39] }\end{array}$} & $\begin{array}{l}\text { Hydrodistillation method, } \\
\text { Analyzed-GC-MS }\end{array}$ & \multirow{4}{*}{$\begin{array}{c}\text { Hexadecanoic acid }(34.0 \%) \text {, oleic } \\
\text { acid }(15.7 \%), 5,6 \text {-dihydro-2,4,6- } \\
\text { triethyl-(4H)-1,3,5-dithiazine } \\
(11.7 \%), \text { methyl oleate }(3.8 \%), \text { and } \\
\text { eudesm-7(11)-en-4-ol }(2.7 \%) \text { [16] }\end{array}$} & $\begin{array}{l}\text { Gingival index score (Chewing } \\
\text { stick)-Pre-intervention }(0.31 \pm 0.44) \\
\text { Post-intervention }(0.16 \pm 0.29)\end{array}$ & \\
\hline & & \multirow{3}{*}{$\begin{array}{l}\text { Essential oil extracted from } \\
\text { seeds [16] }\end{array}$} & & $\begin{array}{l}\text { Dose-Neem (chewing stick) } \\
20 \mathrm{~cm} \times 20 \mathrm{~mm},\end{array}$ & \\
\hline & & & & Application: Chewing & \\
\hline & & & & [40] & $\begin{array}{c}\text { Neem bark extract used in toothpaste } \\
\text { or tooth powder. Leaf extract used in } \\
\text { mouth rinses [41] }\end{array}$ \\
\hline \multirow[b]{2}{*}{$\begin{array}{l}\text { Acorus calamus L. } \\
\text { (Sweet flag, Vacha) }\end{array}$} & \multirow{2}{*}{$\begin{array}{l}\text { India, Central Asia, Eastern } \\
\text { Europe, Jammu Kashmir, } \\
\text { Himachal Pradesh, Manipur, } \\
\text { Naga land, Uttarakhand [19] }\end{array}$} & $\begin{array}{l}\text { Steam distillation method, } \\
\text { Analyzed- GC-MS }\end{array}$ & & & \\
\hline & & $\begin{array}{l}\text { Essential oil extracted from } \\
\text { leaves [42] }\end{array}$ & $\begin{array}{l}\alpha \text {-Asarone }(16.54 \%),(\mathrm{E}) \text {-Methyl } \\
\text { isoeugenol }(5.06 \%), \gamma \text {-Cadinene } \\
\text { (3.00)\%, } \alpha \text {-pinene }(2.96 \%) \text { and } \\
\text { Citronellal }(2.82 \%)[42]\end{array}$ & $\begin{array}{c}\text { In vitro antioxidant activity of Acorus } \\
\text { calamus (rhizome). DPPH method: } \mathrm{IC}_{50} \\
\text { value (acetone extract of rhizome)-5 } \\
\mu \mathrm{g} / \mathrm{mL}[43]\end{array}$ & $\begin{array}{l}\text { Rhizome part is used for the treatment } \\
\text { of dental disorders [44] }\end{array}$ \\
\hline \multirow{3}{*}{$\begin{array}{l}\text { Juglans regia L. (Walnut, } \\
\text { Akhrot) }\end{array}$} & \multirow{3}{*}{$\begin{array}{l}\text { China, United State, Jammu } \\
\text { and Kashmir, Himachal } \\
\text { Pradesh, Arunachal Pradesh, } \\
\text { Uttarakhand [21] }\end{array}$} & \multirow{3}{*}{$\begin{array}{l}\text { Hydrodistillation method, } \\
\text { Analyzed GC-MS, } \\
\text { GC-FIDEssential oil extracted } \\
\text { from leaves [45] }\end{array}$} & $\begin{array}{l}\text { Caryophyllene oxide (16.9 to } \\
27.4 \% \text { ), }\end{array}$ & $\begin{array}{l}\text { In vivo (clinical trial) effect of Juglans } \\
\text { regia dental plaque in humans, Dose: } \\
\text { twice/day ( } 3 \text { days), }\end{array}$ & \multirow{3}{*}{$\begin{array}{c}\text { Bark extract used in oral cavity hygiene, } \\
\text { treatment of gingivitis, dental plaque, } \\
\text { cleaning of teeth [21] }\end{array}$} \\
\hline & & & $\begin{array}{l}\beta \text {-Caryophyllene ( } 4.0 \text { to } 22.5 \%) \\
\text { Germacrene (1.2 to } 9.4 \% \text { ) and }\end{array}$ & $\begin{array}{l}2 \% \text { ether extract (bark) reported } \\
\text { maximum plaque inhibition }(32 \%),\end{array}$ & \\
\hline & & & $\beta$-Pinene (2.8 to 9.5\%) [45] & $\begin{array}{l}\text { Application: extract directly applied on } \\
\text { tooth surface [46] }\end{array}$ & \\
\hline
\end{tabular}


Table 2. Cont.

\begin{tabular}{|c|c|c|c|c|c|}
\hline $\begin{array}{l}\text { Botanical Name } \\
\text { (Common Name) }\end{array}$ & Location & $\begin{array}{c}\text { Extraction Method or Type of } \\
\text { Solvent }\end{array}$ & Essential Oil Components & $\begin{array}{l}\text { Study Type (In Vitro/In Vivo/Clinical } \\
\text { Trial) and Dose of the Extract }\end{array}$ & Role in Oral Health \\
\hline \multirow{3}{*}{$\begin{array}{l}\text { Asparagus racemosus } \\
\text { (Satavari) }\end{array}$} & \multirow{3}{*}{$\begin{array}{l}\text { Sri Lanka, India, Himalayas, } \\
\text { Australia, Africa [17] }\end{array}$} & $\begin{array}{l}\text { Solvent extraction method, } \\
\text { Analyzed by GC-MS }\end{array}$ & \multirow{3}{*}{$\begin{array}{c}\text { Borneol }(26.40 \%), \text { myrtanol } \\
(13.72 \%), \text { pinocarveol }(2.37 \%) \\
\text { 2-ethylhexanol }(1.76 \%) \\
\text { perillaldehyde }(8.97 \%)[47,48]\end{array}$} & $\begin{array}{l}\text { In vitro antioxidant activity of root } \\
\text { extract, }\end{array}$ & \\
\hline & & \multirow{2}{*}{$\begin{array}{l}\text { Essential oil extracted from aerial } \\
\text { parts }[47,48]\end{array}$} & & $\begin{array}{l}\text { DPPH method: } \mathrm{IC}_{50} \text { value (ethanolic } \\
\text { extract of root) }-468.57 \pm 3.002 \mu \mathrm{g} / \mathrm{mL}\end{array}$ & \\
\hline & & & & [49] & $\begin{array}{l}\text { Antibacterial properties against caries } \\
\text { causing oral pathogens [50] }\end{array}$ \\
\hline \multirow{4}{*}{$\begin{array}{l}\text { Melaleuca alternifolia } \\
\quad \text { (Tea tree oil) }\end{array}$} & \multirow{4}{*}{$\begin{array}{l}\text { India (Ansari et al., 2006), } \\
\text { Australia [51] }\end{array}$} & \multirow{4}{*}{$\begin{array}{l}\text { Steam distillation method, } \\
\text { analyzed by GC and GC-MS, } \\
\text { essential oil extracted from leaves } \\
\text { and terminal branches [52] }\end{array}$} & \multirow{4}{*}{$\begin{array}{c}\text { Terpinen-4-ol, } p \text {-cymene, } \\
\alpha \text {-terpinene, } \gamma \text {-terpinene, } \\
1,8 \text {-cineole, } \alpha \text {-pinene and } \\
\alpha \text {-terpinol [52] }\end{array}$} & $\begin{array}{l}\text { In vivo (clinical trial) effect of Melaleuca } \\
\text { alternifolia essential oil on dental plaque } \\
\text { in humans in the form of toothpaste } \\
\text { along with ethanolic extract of Polish } \\
\text { propolis. }\end{array}$ & \\
\hline & & & & $\begin{array}{l}\text { Comparison after } 7 \text { and } 28 \text { days of } \\
\text { using toothpaste. }\end{array}$ & \\
\hline & & & & $\begin{array}{l}\text { Result: Approximal plaque index } \\
\text { (API)-Before treatment; } \\
64.58 \pm 22.38 \% \text {. After treatment, }\end{array}$ & \\
\hline & & & & $\begin{array}{c}7 \text { days- }(49.00 \pm 25.32 \%, p<0.006) \text { and } \\
\text { after } 28 \text { days- }(39.39 \pm 20.60 \% \\
p<0.0002)[53]\end{array}$ & $\begin{array}{l}\text { Periodontitis [54], Relieve from bad } \\
\text { breath, bleeding gums, and plaque [55] }\end{array}$ \\
\hline \multirow{3}{*}{ Acacia nilotica (Babul) } & \multirow{3}{*}{$\begin{array}{l}\text { India, Nepal, Pakistan, } \\
\text { Arabian Peninsula, Africa, } \\
\text { South Africa, Egypt [56] }\end{array}$} & \multirow{3}{*}{$\begin{array}{c}\text { Hydrodistillation method and } \\
\text { analyzed by GC-FID and GC/MS. } \\
\text { Essential oil extracted from the } \\
\text { bark, leaves [57] }\end{array}$} & \multirow{3}{*}{$\begin{array}{c}\text { Menthol }(34.9 \%) \text {, limonene } \\
(15.3 \%), \alpha \text {-Curcumene }(6.9 \%) \text { and } \\
\text { carvacrol }(4.1 \%)[57]\end{array}$} & $\begin{array}{l}\text { In vitro (antibacterial) on Lactobacillus } \\
\text { acidophilus, Streptococcus sanguinis, S. } \\
\text { salivarius, and Aggregatibacter } \\
\text { actinomycetemcomitans. }\end{array}$ & To cure mouth ulcers [56], \\
\hline & & & & $\begin{array}{l}\text { Dosage: Concentration of extract } \\
\text { ranging between } 5 \text { and } 30 \mathrm{~mL} \text { in } \\
\text { different test tubes. Incubated at } 37^{\circ} \mathrm{C} \\
\text { for } 24 \mathrm{~h} \text {. }\end{array}$ & $\begin{array}{l}\text { To treat toothache and for cleaning } \\
\text { teeth [58], }\end{array}$ \\
\hline & & & & $\begin{array}{c}\text { MIC value of bark extract of } \\
\text { Lactobacillus acidophilus, Streptococcus } \\
\text { sanguinis, S. salivarius, Aggregatibacter } \\
\text { actinomycetemcomitans is 40,35,35, and } \\
45 \text {, respectively [59] }\end{array}$ & and for sore throat [60] \\
\hline
\end{tabular}


Table 2. Cont

\begin{tabular}{|c|c|c|c|c|c|}
\hline $\begin{array}{l}\text { Botanical Name } \\
\text { (Common Name) }\end{array}$ & Location & $\begin{array}{c}\text { Extraction Method or Type of } \\
\text { Solvent }\end{array}$ & Essential Oil Components & $\begin{array}{l}\text { Study Type (In Vitro/In Vivo/Clinical } \\
\text { Trial) and Dose of the Extract }\end{array}$ & Role in Oral Health \\
\hline \multirow[t]{2}{*}{ Quercus infectoria (Baloot) } & \multirow[t]{2}{*}{$\begin{array}{l}\text { India, Nepal, Iran, Greece, } \\
\text { Syria [61] }\end{array}$} & \multirow{2}{*}{$\begin{array}{l}\text { Steam distillation (Clevenger } \\
\text { apparatus)-Aqueous and } \\
\text { ethanolic extract of essential oil } \\
\text { from the galls [61] }\end{array}$} & \multirow[t]{2}{*}{$\begin{array}{l}\text { Tannins } 50-70 \% \text {, gallic acid } \\
(2-4 \%) \text {, ellagic acid [61] }\end{array}$} & $\begin{array}{l}\text { In vitro study for dental caries and } \\
\text { plaque. Methanol and acetone extracts } \\
\text { were screened against bacteria } \\
\text { Streptococcus mutans ATCC } 25175, \\
\text { Streptococcus salivarius ATCC 13419, } \\
\text { Porphyromonas gingivalis ATCC 33277, } \\
\text { and Fusobacterium nucleatum } \\
\text { ATCC } 25586 .\end{array}$ & \multirow[t]{2}{*}{$\begin{array}{l}\text { Used to treat gum infections, gingivitis, } \\
\text { and toothache [62] }\end{array}$} \\
\hline & & & & $\begin{array}{l}\text { MIC value of methanol and acetone } \\
\text { extract is } 0.16 \text { and } 0.63 \mathrm{mg} / \mathrm{mL} \text {, } \\
\text { respectively, while } \mathrm{MBC} \text { value for } \\
\text { methanol and acetone extract is } \\
0.31-1.25 \mathrm{mg} / \mathrm{mL} \text { and } 0.31-2.50 \\
\mathrm{mg} / \mathrm{mL} \text {, respectively [62] }\end{array}$ & \\
\hline $\begin{array}{l}\text { Artemisia dracunculus } \\
\text { (Estragon) }\end{array}$ & Asia and central Europe & $\begin{array}{l}\text { Hydrodistillation method for } \\
\text { extraction and GC-MS method } \\
\text { for the identification. Extraction } \\
\text { of essential oil from aerial } \\
\text { parts [61] }\end{array}$ & $\begin{array}{l}\text { Estragol (methyl chavicol), (E)- } \\
\text { anethole, capillene, methyl } \\
\text { eugenol, }(\mathrm{E})-\beta \text {-ocimene, } \\
\text { (E)- } \alpha \text {-ocimene, (Z)- } \beta \text {-ocimene } \\
\text { limonene, } \alpha \text {-pinene, } \\
\alpha \text {-terpinolene, isoelemicin, } \\
\text { elemicin 5-phenyl-1,3- } \\
\text { pentadiyne, } \alpha \text {-phellandrene, } \\
\beta \text {-phelland-rene, pulegone, } \\
\text { (Z)-artemidin, hinokitiol, and } \\
\text { acenaphthene [63] }\end{array}$ & $\begin{array}{c}\text { In vitro(antibacterial) on Staphylococcus } \\
\text { aureus (ATCC 23235). } \\
\text { Concentration-10 } \mu \mathrm{L} \text { of tarragon oil } \\
\text { tested on agar plate. MIC value is } \\
1250 \mu \mathrm{g} / \mathrm{mL} \text { after } 24 \mathrm{~h} \text { of incubation } \\
\text { period and MBC value is } 2500 \mu \mathrm{g} / \mathrm{mL} \\
{[63,64]}\end{array}$ & $\begin{array}{l}\text { To treat bleeding gums (gingiva) and } \\
\text { bad breath [63] }\end{array}$ \\
\hline
\end{tabular}


Table 2. Cont.

\begin{tabular}{|c|c|c|c|c|c|}
\hline $\begin{array}{l}\text { Botanical Name } \\
\text { (Common Name) }\end{array}$ & Location & $\begin{array}{c}\text { Extraction Method or Type of } \\
\text { Solvent }\end{array}$ & Essential Oil Components & $\begin{array}{l}\text { Study Type (In Vitro/In Vivo/Clinical } \\
\text { Trial) and Dose of the Extract }\end{array}$ & Role in Oral Health \\
\hline \multirow{3}{*}{ Streblus asper (Koi) } & \multirow{3}{*}{$\begin{array}{l}\text { Southern China, India, Sri } \\
\text { Lanka, Malaysia, The } \\
\text { Philippines, Malaysia, } \\
\text { Thailand [65] }\end{array}$} & \multirow{3}{*}{$\begin{array}{l}\text { Extraction by Hydrodistillation } \\
\text { and analyzed by GC-MS method } \\
\text { and GC-FID method [66]. } \\
\text { Essential oil extracted from aerial } \\
\text { parts }\end{array}$} & $\begin{array}{c}\text { Leaves: phytol }(45.1 \%), \\
\text { trans-farnesyl acetate }(5.8 \%), \\
\alpha \text {-farnesene }(6.4 \%), \\
\text { trans-trans- } \alpha \text {-farnesene }(2.0 \%) \\
\text { and caryophyllene }(4.9 \%)[66]\end{array}$ & $\begin{array}{l}\text { Leaf extract tested for plaque formation } \\
\text { and gingivitis caused by Streptococcus } \\
\text { mutans and Actinomycetemcomitans by } \\
\text { using disc diffusion method on } \\
\text { agar surface. }\end{array}$ & \multirow{3}{*}{$\begin{array}{l}\text { Dental caries (Wongkhan et al., 2001), } \\
\text { strengthening gums, toothache, and } \\
\text { gingivitis [65] }\end{array}$} \\
\hline & & & $\begin{array}{c}\text { Stem bark: } \alpha \text {-amyrin acetate, } \\
\beta \text {-sitosterol, Strebloside, lupeol } \\
\text { acetate, diol, Sioraside, } \alpha \text {-amyrin, } \\
\text { mansonin, (7'S, } \\
\text { 8'S)-trans-streblusol A, (7'S, } \\
\text { 8'S)-threo-streblusol B, } \\
\text { streblusquinone, 8'R-streblusol C, } \\
\text { streblusol E and (8R, } \\
\text { 8'R)-streblusol D [65] }^{\prime}\end{array}$ & \multirow{2}{*}{$\begin{array}{l}\text { The baseline mean of the plaque index is } \\
2.42 \text { in the chlorohexinde group, } 1.25 \text { in } \\
\text { the placebo group, } 2.22 \text { Streblus asper } \\
\text { alcoholic extract group, and } 2.31 \text { in } \\
\text { Streblus asper aqueous extract group. The } \\
\text { baseline mean of the gingival index is } \\
2.12 \text { in the chlorohexidine group, } 2.23 \text { in } \\
\text { the Streblus asper alcoholic extract group, } \\
\text { and } 2.13 \text { in the Streblus asper aqueous } \\
\text { extract group was found to be } \\
\text { statistically significant } p \geq 0.001 \text {. Swab } \\
\text { from mouth is collected. Duration of test } \\
\text { is } 21 \text { days [67]. }\end{array}$} & \\
\hline & & & $\begin{array}{l}\text { Aerial bark: n-Triacontane, } \\
\beta \text {-sitosterol, Stigmasterol, } \\
\text { tetraiacontan-3-one, oleanolic } \\
\text { acid and botulin [65] }\end{array}$ & & \\
\hline
\end{tabular}


Table 2. Cont.

\begin{tabular}{|c|c|c|c|c|c|}
\hline $\begin{array}{l}\text { Botanical Name } \\
\text { (Common Name) }\end{array}$ & Location & $\begin{array}{c}\text { Extraction Method or Type of } \\
\text { Solvent }\end{array}$ & Essential Oil Components & $\begin{array}{l}\text { Study Type (In Vitro/In Vivo/Clinical } \\
\text { Trial) and Dose of the Extract }\end{array}$ & Role in Oral Health \\
\hline Vitex negundo (Nirgundi) & $\begin{array}{l}\text { Afghanistan, India, Sri } \\
\text { Lanka, Pakistan, Thailand, } \\
\text { eastern Africa, Malaysia, } \\
\text { Madagascar [72] }\end{array}$ & $\begin{array}{l}\text { Hydrodistillation method for } \\
\text { extraction and analysis by GC } \\
\text { and GC-MS method. Essential oil } \\
\text { extracted from leaves, flowers } \\
\text { and dried fruits [73] }\end{array}$ & $\begin{array}{c}\delta \text {-guaiene, epoxide, } \\
\text { ethyl-hexadecenoate, } \\
\text { guaia-3,7-dienecaryophyllene } \\
\text { epoxide, } \alpha \text {-selinene, } \\
\text { caryophyllene epoxide, } \\
\text { germacren-4-ol } \beta \text {-selinene, } \\
\text { (E)-nerolidol, } \alpha \text {-cedrene, } \\
\text { germacrene D, hexadecanoic acid, } \\
\text { p-cymene, valencene, } \\
\text { germacrene, D viridiflorol } \\
(19.55 \%), \beta \text {-caryophyllene } \\
(16.59 \%), \text { sabinene (12.07\%), } \\
\gamma \text {-terpinene (2.21\%), 4-terpineol } \\
(9.65 \%), \text { caryophyllene oxide } \\
(1.75 \%), 1 \text {-oceten-3-ol (1.59\%), } \\
\text { 1-oceten-3-ol (1.59\%) and } \\
\text { globulol }(1.05 \%)[74]\end{array}$ & $\begin{array}{l}\text { In vitro study on Streptococcus mutans, } \\
\text { Streptococcus sanguis, and Staphylococcus } \\
\text { aureus. The aqueous, methanolic, and } \\
\text { petroleum ether extract of Vitex negundo } \\
\text { were tested for their antibacterial } \\
\text { activity using well diffusion method. } \\
\text { Concentration: } 200 \mathrm{mg} / \mathrm{mL} \text {. Maximum } \\
\text { inhibition zone is shown by methanolic } \\
\text { extract is } 23 \mathrm{~mm} \text { [75] }\end{array}$ & $\begin{array}{l}\text { Toothache, throat pain, mouth ulcers } \\
\text { (Ullah et al., 2012). The decoction } \\
\text { prepared from the leaves of Vitex } \\
\text { negundo is used for gargling in the } \\
\text { treatment of mouth ulcers [76] }\end{array}$ \\
\hline \multirow[t]{3}{*}{$\begin{array}{l}\text { Rosmarinus officinalis } \\
\text { (Rosemary) }\end{array}$} & \multirow[t]{3}{*}{$\begin{array}{l}\text { South Europe, India, } \\
\text { Mediterranean basin [77] }\end{array}$} & \multirow{3}{*}{$\begin{array}{l}\text { Hydrodistillation for extraction } \\
\text { (Elyemni et al., 2019) and } \\
\text { analysis by HPLC and gas } \\
\text { chromatography. Extraction of } \\
\text { essential oil from leaves [78] }\end{array}$} & \multirow{3}{*}{$\begin{array}{c}\text { Borneol (1.5-5.0\%), camphor } \\
\text { (5-31\%), pinene }(9-26 \%) \text {, } \\
\text { 1,8-cineol (15-55\%), camphene } \\
(2.5-12.0 \%), \text { pinene }(2.0-9.0 \%), \\
\text { limonene }(1.5-5.0 \%), \text { myrcene } \\
(0.9-4.5 \%), \text { verbenone }(2.2-11.1 \%) \\
\text { and caryophyllene }(1.8-5.1 \%)[79]\end{array}$} & $\begin{array}{l}\text { Clinical trial on the action of toothpaste } \\
\text { made from the extract of Rosmarinus } \\
\text { officinalis on humans divided into two } \\
\text { groups (experimental and controlled), } \\
\text { assessed at baseline and } 30 \text { days after } \\
\text { the study using the gingival bleeding } \\
\text { index (GBI) and the plaque index (PI). }\end{array}$ & \multirow[t]{3}{*}{ Plaque [79], dental caries [80] } \\
\hline & & & & $\begin{array}{l}\text { Results: reduction of } 38 \% \text { in the risk of } \\
\text { gingival bleeding (relative and } \\
\text { absolute) }\end{array}$ & \\
\hline & & & & $\begin{array}{l}\text { And reductions in bacterial plaque is } \\
\qquad 22.7 \%[80]\end{array}$ & \\
\hline Embelia ribes (Vaibidang) & $\begin{array}{l}\text { Sri Lanka, China, India, } \\
\text { Malaysia [81] }\end{array}$ & $\begin{array}{l}\text { Soxhlet extraction and analysis } \\
\text { by FT-IR, DSC, UV-visible, NMR, } \\
\text { X-ray diffraction, and TGA } \\
\text { method. Extraction of essential } \\
\text { oil from berries [82] }\end{array}$ & $\begin{array}{l}\text { Embelin, embolic acid, rapanone } \\
\text { [81] and vilangin [83] }\end{array}$ & $\begin{array}{l}\text { The extract of Embelia ribes at a } \\
\text { concentration of } 500 \mathrm{mg} / 50 \mathrm{~mL} \\
\text { reported } 12 \mathrm{~mm} \text { diameter of zone of } \\
\text { inhibition against test organism Bacillus } \\
\text { subtilis, causing periodontitis and tooth } \\
\text { decay [84]. }\end{array}$ & $\begin{array}{l}\text { Dental cavities, as mouthwash, gum } \\
\text { infection, and tooth decay [85] }\end{array}$ \\
\hline
\end{tabular}


Table 2. Cont.

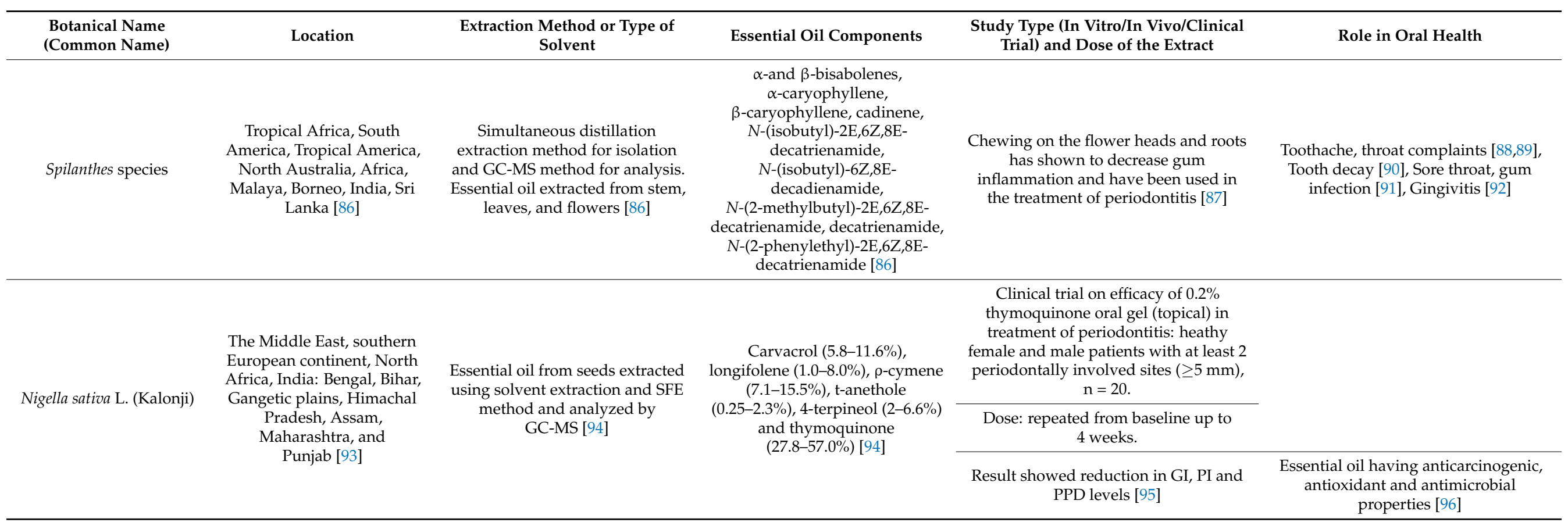



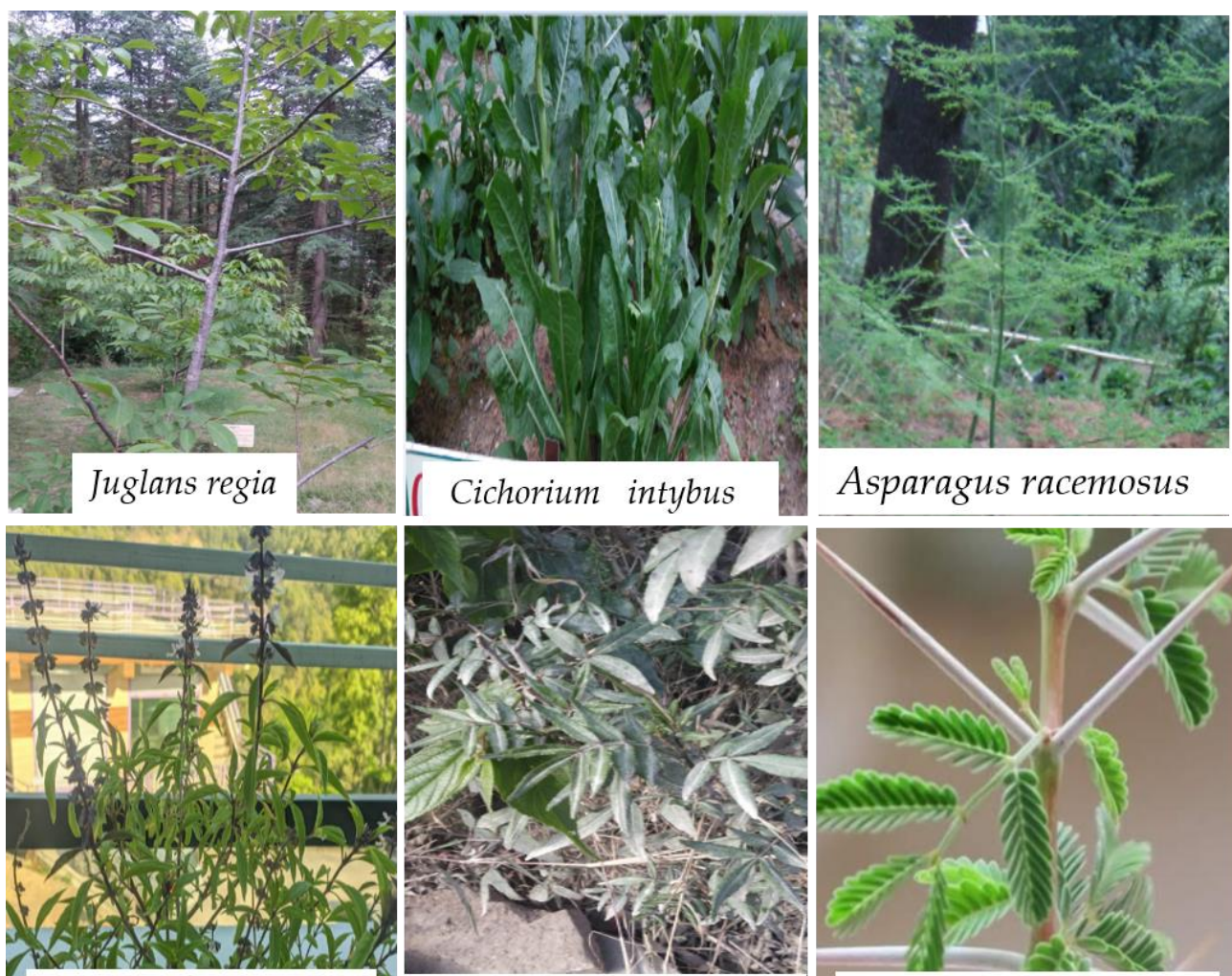

Asparagus racemosus

Ocimum sanctum

Zanthoxylum armatum
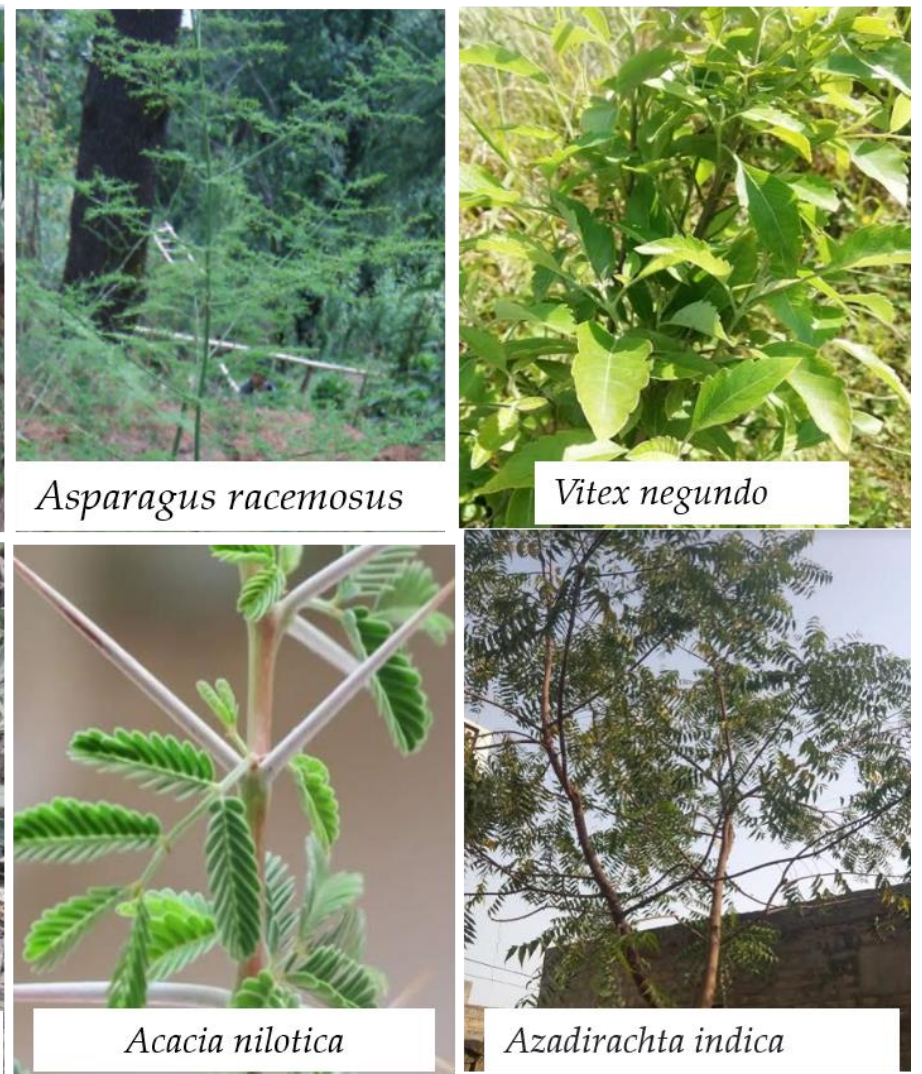

Figure 1. Photographs showing important medicinal plants with a beneficial role in oral health.

\section{Methodology}

The current review focus on the beneficial effect of secondary metabolites derived from medicinal plants in oral health. The eligibility of studies includes the following inclusion criteria: (i) medicinal plants that were having less reviewed literature and found rarely were selected; (ii) studies published in the English language were included; (iii) original studies were selected that examined the efficacy of essential oils in oral health; and (iv) in vivo and clinical trial studies were selected on the basis of authenticity. Exclusion criteria: (i) studies not published in English; (ii) in vivo studies not followed ethical guidelines; (iii) studies not available in full text. A literature search is carried out on Scopus, PubMed, Google Scholar, Elsevier, and Springer using the following keywords in combination: oral health, essential oils, medicinal plants, phytochemicals, periodontitis, dental caries, dental plaque, gingivitis, in vitro, in vivo studies, clinical trials, microbial infections. The last search was performed on 10 May 2021. A total of 417 records were found during database searches. In the first filter, a total of 164 duplicate records were removed. Then, articles that follow eligibility criteria were selected. The following data were collected from studies:

The names of plants were followed according to the plant list [97]. The essential oil composition of plant parts, their extraction method, and solvent used. In vitro, in vivo studies, and clinical trials: effect of EOs on various infections, the concentration of EOs used, study subjects, method of application. For the selection, Preferred Reporting Items for Systematic Reviews and Meta-Analyses (PRISMA) 2020 guidelines were followed [98]. The selection process, including identification, number of records identified, eligibility criteria, and screening, is demonstrated in PRISMA flow diagram Figure 2. 


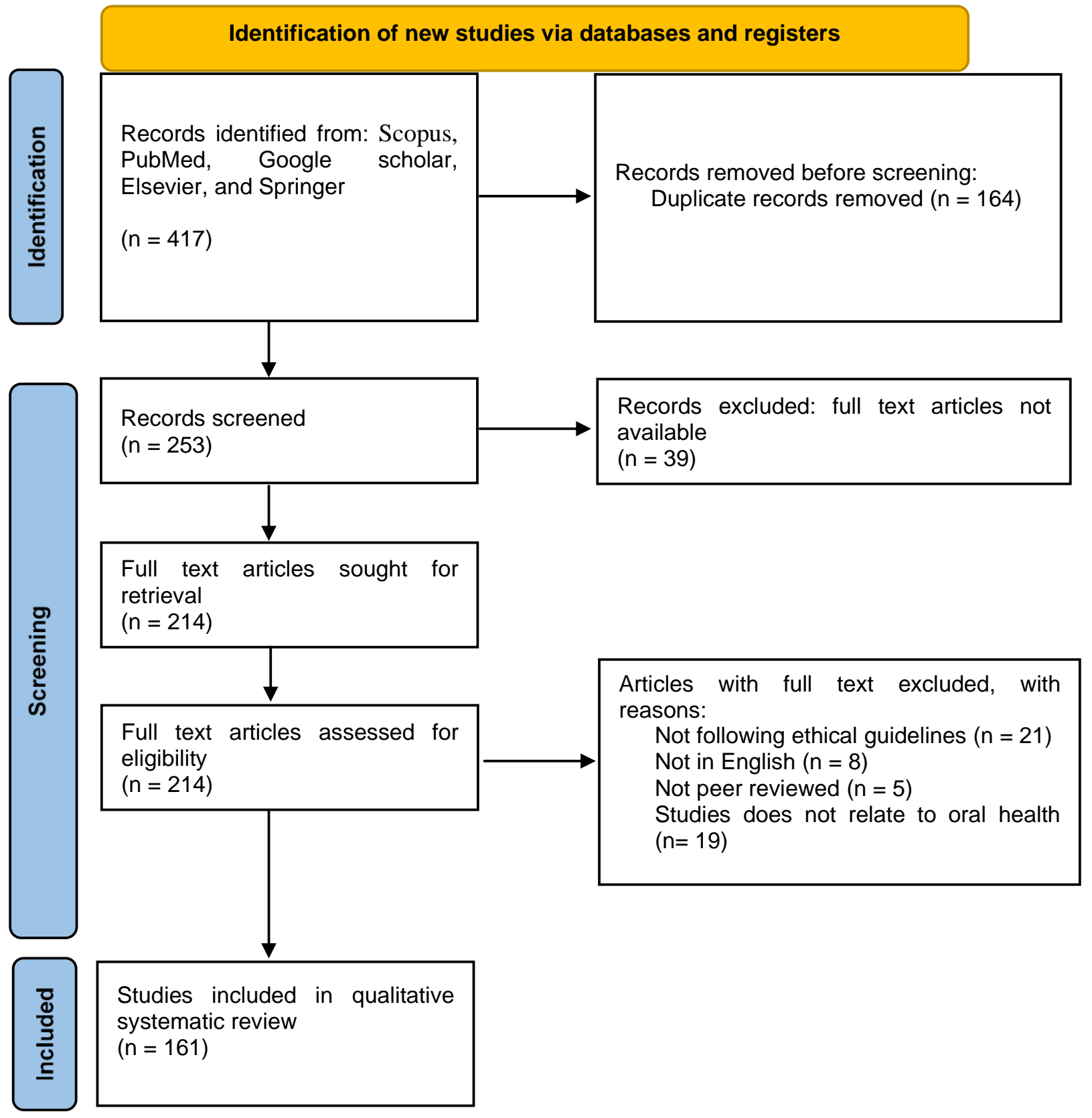

Figure 2. PRISMA flow diagram for the selection process of studies included in qualitative systematic review.

\section{Medicinal Plants and Beneficial Role in Oral Health}

\subsection{Zanthoxylum armatum DC. (Tejphal)}

Zanthoxylum armatum belongs to the family Rutaceae. Globally, Zanthoxylum armatum is found in countries such as Nepal, Malaysia, the Philippines, China, Pakistan, Japan, and Taiwan at an altitude range of 1300 to $1500 \mathrm{~m}$ [23]. It is distributed in India from Kashmir to Bhutan up to an altitude of $2500 \mathrm{~m}$ [99]. Zanthoxylum species are used to treat dental disorders, which include Zanthoxylum armatum DC., Zanthoxylum acanthopodium DC., Zanthoxylum alatum Roxb., Zanthoxylum capense (Thuanb.) Harv., Zanthoxylum americanum Mill., Zanthoxylum macrophylla Engl., Zanthoxylum rhetsa Roxb., Zanthoxylum rhoifolium Lam., Zanthoxylum xanthoxyloides Waterm, and Zanthoxylum chalybeum Engl. [100,101]. Different plant parts of Zanthoxylum species such as leaves, fruits, stems, bark, seeds, and roots are found to be enriched with various secondary metabolites viz. alkaloids, sterols, phenolics, lignins, coumarins, and terpenoids. The bark powder of Zanthoxylum armatum, upon 
mixing with honey, gives relief against gum bleeding. The extract of the toothache tree (Zanthoxylum) is used for the treatment of inflammatory pain (toothache) [25].

EOs of Zanthoxylum armatum is extracted from leaves, and analysis performed through gas chromatography. Major constituents in Zanthoxylum armatum such as linalool (53.05\%), bergamot mint oil $(12.73 \%)$, limonene di epoxide $(11.39 \%), \alpha$-pinene $(4.08 \%), \beta$-myrcene $(3.69 \%)$, and $\beta$-limonene (3.10\%) were reported in earlier studies [23]. Staphylococcus aureus has been reported as a pathogen causing infections related to dental implants [102]. Antibacterial activity of EOs extracted from the leaf of Z. armatum is found to be effective against all tested bacterial strains, i.e., Escherichia coli, Pseudomonas aeruginosa, Micrococcus leutus, Staphylococcus aureus, Pasteurella multocida, Bacillus subtilis, and Streptococcus viridians [103]. The antibacterial activities of EOs of Zanthoxylum armatum might be due to the presence of terpenoids [24]. The hydroxy- $\alpha$-sanshool alkyl amide extract of Zanthoxylum plants inhibits neurons that mediate sharp acute pain and inflammatory pain by blocking voltage-gated sodium channel. This is consistent with its analgesic effects in humans. Under naive and inflammatory conditions, sanshool treatment in mice produced a selective attenuation of mechanical sensitivity, with no effect on thermal sensitivity [104].

\subsection{Ocimum sanctum L. (Tulsi)}

Ocimum sanctum belongs to the Lamiaceae family, and distribution covers the entire Indian sub-continent. It has been found at an altitude range of $1800 \mathrm{~m}$ in the Himalayas. The primary centers of diversity of the genus Ocimum were located in Asia, Africa, and Brazil. The main countries of Ocimum sanctum cultivation are Haiti, Hungary, Comoro Islands, Bulgaria, Thailand, and India. The essential oil is extracted from Ocimum basilicum and Ocimum sanactum and examined for in vitro antibacterial activity. The result has shown that essential oil has effective antibacterial activity against aerobic and anaerobic organisms commonly present in the oral cavity [105].

Using hydrodistillation method, essential oil is obtained from dry leaves of Ocimum sanctum. Further analyzed by GC-MS (gas chromatography-mass spectroscopy), essential oil composition was found to be a mixture of alcohols (19.326\%), oxides $(3.252 \%)$, and hydrocarbons (26.463\%). These hydrocarbons present in form of caryophyllene (22.265\%), $\alpha$-pinene $(0.125 \%), \alpha$-caryophyllene $(2.071 \%), \alpha$-bourboene $(0.244 \%), \alpha$-cubebene $(0.123 \%)$, copaene $(1.637 \%)$ and camphene $(0.121 \%)$. Alcohols are present in the form of methyl isoeugenol $(2.952 \%)$, eugenol $(15.906 \%)$, and borneol $(0.468 \%)$. Whereas in oxides, caryophyllene oxide $(3.252 \%)$ was found in a significant amount [27]. Essential oils are extracted from fresh and dry parts of plants with steam distillation and hydrodistillation methods. Then analyzed with GC-MS, the main constituents found in the extract of dry leaves with hydrodistillation method were cis-sabinene hydrate (2.84\%), linalool (6.69\%), and cis-sabinene hydrate $(2.84 \%)$, with $0.20 \%$ yield. The chief constituent from fresh leaves of Ocimum sanctum is spathulenol $(13.92 \%)$, $\beta$-eudesmol $(11.5 \%)$, and methyl chavicol $(27.64 \%)$, with $0.18 \%$ yield (Milani et al., 2016). Eugenol is one of the active components found in Ocimum sanctum and is found to be responsible for therapeutic potential [106]. Eugenol is extensively used in dentistry for the treatment of toothache and pulpitis [107]. Due to the occurrence of eugenol, Ocimum sanctum acts as a cyclooxygenase (COX)-2 inhibitor. The leaves comprise $0.7 \%$ essential oil, including $20 \%$ methyl eugenol and $70 \%$ eugenol; hence, it provides relief from toothache problems [29]. The study on in vitro antifungal activity of essential oil extracted from Ocimum sanctum and its components eugenol and linalool against Candida albicans and Candida tropicalis known to cause oral candidiasis, shows the essential oil to be effective among Candida strains [108]. Antibacterial efficacy of Ocimum sanctum in ethanolic extract against Streptococcus mutans (pathogenic bacteria causing dental caries) was due to the presence of ursolic acid, carvacrol, and eugenol (1-hydroxy-2-methoxy-4-allylbenzene) [109]. 


\subsection{Salvadora persica L. (Miswak)}

Salvadora persica has its place in the Salvadoraceae family and is distributed among South and West Asia, Southern, East, and North Africa, and in the Arabic Peninsula. Salvadora persica is mostly found throughout the arid region in India and found in altitude range up to $1800 \mathrm{~m}$. It flourishes in areas with readily accessible groundwater is readily such as riverbanks, waterholes, along drainage lines, and desert floodplains. It commonly occurs in grassy savannahs, in valleys, and thorn scrub. In Arabic countries, the stem of Salvadora persica is extensively used as decoctions and chewing sticks. Salvadora persica comprises compounds having antibacterial efficiency and plaque-inhibiting properties against cariogenic bacteria commonly present in the oral cavity [30]. The roots and small branches of Salvadora persica were used to prepare toothbrush and is found to be useful as maintainer of teeth. It is used worldwide to treat toothache and tooth cleaning [110]. Miswak has various traditional medicinal uses to treat disease associated with oral hygiene or dental care due to the presence of unique biologically active compounds, phytochemicals, and minerals [111]. Salvadora persica has been used in a probiotic spray, chewing gum, dental cement, chewing stick, toothpaste, aqueous extract, mouthwash, ethanol extract, dental varnish, and essential oil. It is found that miswak is effective as an antigingivitis, with whitening, orthodontic chain preservation, biocompatibility with oral cells, anticariogenic, promotion of gingival wound healing, and antiplaque properties [10].

Essential oil of Salvadora persica is extracted with hydrodistillation method from stem part. Further chemical composition is analyzed by GC-MS, and it shows a mixture of oxygenated monoterpenes (54\%), sesquiterpene hydrocarbons $(21 \%)$, and monoterpene hydrocarbons $(11 \%)$, out of which the main constituents were $\alpha$-caryophellene $(13.4 \%)$, 9-epi-(E.)-caryophellene, 1,8-cineole (eucalyptol) $(46 \%)$ and $\beta$-pinene (6.3\%) [31]. A recent study on the essential oil of Salvadora persica showed that these oils are very effective as an antimicrobial agent in oral hygiene [112].

\subsection{Eucalyptus globulus Labill. (Nilgiri)}

Eucalyptus globulus is a type of shrubby plant that belongs to the family Myrtaceae. Eucalyptus globulus is commonly known as Nilgiri. There are around 700 species of the Eucalyptus genus, and it is widely used for various purposes, distributed among many countries such as Albina, Spain, Uganda, Cambodia, Nepal, and the United Kingdom [33]. In India, Eucalyptus globulus is commonly found in Andhra Pradesh, Bihar, Goa, Gujrat, Haryana, Punjab, Uttar Pradesh, Tamil Nadu, Kerala, and Karnataka [113]. The plant Eucalyptus saligna is used as a mouthwash gargle in the Cameroon region (a central African country) to treat toothache, sore throat, halitosis. The essential oil of Eucalyptus globulus extracted from leaves shows to have antimicrobial efficacy against Staphylococcus aureus (Gram-positive bacteria) and Escherichia coli (Gram-negative) found in the oral cavity [114,115]. The essential oil of Eucalyptus globulus was analyzed using GC-MS, and a total of 27 compounds were found. The chief compounds are $\beta$ - pinene $18.54 \%$, eucalyptol (1,8-cineole) $54.79 \%$, $\alpha$ - pinene $11.46 \%$, $\alpha$-phellandrene $2.06 \%$, gamma-eudesmol $1.20 \%$, para cymene $1.60 \%$, and $\beta$-eudesmol $4.68 \%$ [34]. One of the main components presents in the essential oil of Eucalyptus globulus is eucalyptol and used for mouthwash and dental preparations as an endodontic solvent [11].

\subsection{Thymus vulgaris L. (Banajwain)}

Thymus vulgaris belongs to the Lamiaceae mint family and is a flowering plant that can grow up to a height of $15-30 \mathrm{~cm}$. It is distributed among the European countries such as Svizzera, France, Italy, Spain, Bulgaria, Ellas, and the Portuguese Republic [36]. In India, banajwain is distributed among the western temperate Himalayas and Nilgiris. Different parts of the Thymus species were used as a remedy to treat toothache by chewing on the affected tooth [37]. Thyme essential oil (1\%) in ethanol was found to have antibacterial properties against pathogenic bacteria Streptococcus mutans and can be used in toothpaste as an ingredient [116]. 
The essential oil was obtained from the leaves of Thymus vulgaris through the steam distillation method. GC-MS analysis shows 24 bioactive compounds and each one having specific activity against different diseases or acting as a drug. The major compounds were found as thymol (3.82\%), $\alpha$-thymol (38.71\%), camphene $(0.13 \%)$, caryophyllene $(0.915 \%)$, humulene $(0.22 \%), \alpha$-terpineol $(0.285 \%)$ and $\rho$-cymene $(2.77 \%)$ [20]. In vitro studies on Thymus vulgaris essential oil shows antimicrobial activity against clinical isolates of pathogenic bacteria Streptococcus mutans, Porphyromonas gingivalis, Streptococcus pyogenes, and Candida albicans. Hence, have antimicrobial properties of essential oil that can be considered to use in aromatherapy for treatment and prevention of oral infections, toothpaste, and mouth rinse [12].

\subsection{Azadirachta indica A. Juss. (Neem)}

Commonly acknowledged as a holy medicinal plant, Azadirachta indica (neem), an evergreen tree belonging to the family Meliaceae, has been widely used in several medicinal treatments. It grows mostly in thorn forests and dry environments throughout India [117]. Neem nurtures well in the altitude range of $1500 \mathrm{~m}$ and is distributed among various countries having dry zones such as Afghanistan, Pakistan, India, Sri Lanka, Saudi Arabia, and tropical Africa $[39,118]$. Various toothpowders and toothpastes contain neem bark as a constituent due to its antibacterial properties. Studies have shown neem oil and bark to be useful in dental, gum health, or to treat dental plaque $[40,119]$. The study shows Azadirachta indica has been used to treat several dental problems by different methods. Bark and leaf extract used to cure cavities or gum disease. Various mouthwashes use neem extract used to treat tooth decay, oral infections, prevent sore and bleeding gums. In India, stems of neem trees are used by people as chewing sticks [120].

From the seeds of Azadirachta indica, the essential oil was extracted by using the hydrodistillation method. The essential oil chemical composition was analyzed with GC and GC-MS. The analysis showed that the chief components are oleic acid (15.7\%), 5, 6-dihydro-2,4.6-triethyl-(4H)-1,3,5-dithiazine (11.7\%), eudesm-7(11)-en-4-ol (2.7\%) hexadecanoic acid (34.0\%) and methyl oleate 3.8\% [16]. The essential oil extracted from leaves of Azadirachta indica was extracted through steam distillation method and solvent extraction method using two solvents: ethanol and hexane. The chemical composition analyses were performed using GC-MS. The main component in steam extracted essential oil were found as diacenaphtho $\left[1,2-\mathrm{j}: 1^{\prime}, 2^{\prime}-1\right]$ fluoranthene $(11.301 \%)$, phenol, eicosane $(9.76 \%)$, (3Ar,6S,9ar)-1,2,3,4,5,6,7,9a-octahydro-8-methyl-3a, 6-metha no-3ah-cyclopentacycloocten10 -one (36.88\%) and 4-((4-methoxyphenyl) methylene) amino)- (11.84\%). The main compounds in ethanol extracted essential oil were found as diacenaphtho[1,2-j:1', $\left.2^{\prime}-1\right]$ fluoranthene $(13.51 \%)$, butanamide, eicosane $(10.259 \%)$ and $N$-(2-methoxyphenyl)-3-oxo$(16.615 \%)$. In the hexane extracted essential oil: n-hexadecanoic acid $(14.688 \%), 9,12,15-$ octadecatrienoic acid, (Z,Z,Z)- (34.719\%), and (3Ar,6S,9ar)-1,2,3,4,5,6,7,9a-octahydro-8methyl-3a,6-methano-3ah-cyclopentacycloocten-10-one $(10.72 \%)$. It was reported that eicosane has antifungal, antibacterial, antitumor, and cytotoxic properties [121].

\subsection{Acorus calamus L. (Sweet flag or Vacha)}

Acorus calamus is commonly known as vacha. It is a tall perennial wetland plant that belongs to the family Acoraceae. Traditionally, leaves and rhizome of vacha were used as medicine to cure various diseases. Acorus calamus is distributed among central Asia, Eastern Europe and grows well at an altitude of about $2200 \mathrm{~m}$. In India, it occurs throughout different states Jammu and Kashmir, Manipur, Nagaland, Uttar Pradesh, Andhra Pradesh, Tamil Nadu, Maharashtra, Uttarakhand, Karnataka, and Himachal Pradesh [19]. Acorus calamus rhizome extract is used by communities of Tirumala hills to cure dental disorders [44]. The aromatic oil extracted from rhizomes of Acorus calamus is used traditionally for medicinal purposes [122]. It is reported that the rhizome part of Acorus calamus possesses numerous pharmacological activities such as CNS depressant, sedative, hypolipidemic, antimicrobial, anticonvulsant, anti-inflammatory, cryoprotective, immunosuppressive, anticancer, and 
antioxidant [19]. Recently an in vivo study was conducted on munident a herbal dentifrice having Acorus calamus as an ingredient was found to be effective in reducing gingival bleeding index score and Streptococcus mutans count [123]. The essential oil is extracted from the leaves of Acorus calamus using the steam distillation method. The chemical composition analyzed using GC and GC-MS has shown a $0.14 \%(\mathrm{v} / \mathrm{w})$ yield of essential oil. The main chemical compounds of essential oil were reported as $\alpha$-asarone $16.54 \%, \gamma$-cadinene (3.0\%), (E)-methylisoeugenol (5.06\%), $\alpha$-pinene $2.96 \%$, citronellal (2.82\%), followed by acoradiene $(0.10 \%)$, tridecanol $(0.10 \%)$, 2-(acetylmethyl)-(+)-3-carene $(0.12 \%)$, 7 -hexadecyne $(0.13 \%)$, and rosoxide $(0.14 \%)$ [42].

\subsection{Juglans regia L. (Walnut, Akhrot)}

Juglans regia (akhrot), belonging to the Juglandaceae family, is known to have various pharmacological activities. It is distributed throughout countries such as China and the United States. In India, it occurs in Himachal Pradesh, Uttarakhand, Jammu and Kashmir, and Arunachal Pradesh. Bark part is used for many medicinal purposes such as oral cavity hygiene, treatment of gingivitis, dental plaque, and cleaning of teeth [21]. It was found that different plant parts of Juglans regia possess various medicinal activities such as anthelmintic, diuretic, detergent, laxative, astringent, depurative, and exhibit antimicrobial activity. The tooth pain cure by putting a green husk piece into a hollow tooth. For dental complaints, decoction of stem bark is used [124]. The Juglans regia has potential use in oral hygiene products due to its antimicrobial properties due to the occurrence of terpenoids, alkaloids, steroids, phenolic compounds, and flavonoids [125]. The study on chemical composition in Juglans regia essential oil found 29 components with a yield of $84.25 \%$ of total essential oil. The essential oil was extracted from walnut leaves using the hydrodistillation method, and further composition was analyzed using Gas chromatography-mass spectrometry (GC-MS) and gas chromatography-flame ionization detector (GC-FID). The analysis showed main compounds in essential oil were $\beta$-pinene (2.8 to $9.5 \%$ ), caryophyllene oxide (16.9 to $27.4 \%$ ), germacrene (1.2 to $9.4 \%$ ), and $\beta$-caryophyllene (4.0 to $22.5 \%$ ). The essential oil of leaves was found to be rich in oxygenated sesquiterpenes (16.9 to $27.4 \%$ ), alcohols (7.6 to 27.8 ), and sesquiterpene hydrocarbon (13.9 to 39.6\%) [45]. In a recent study, Juglans regia extract containing bioactive compound juglone showed antibiofilm and growth inhibitory activity for oral pathogen, i.e., Porphyromonas gingivalis. In vivo study on the extract of septa and leaves showed low toxicity in mice and rats [126]. In vitro antimicrobial study shows Juglans regia to have antiplaque activity against pathogenic microorganisms associated with dental caries: Streptococcus sobrinus, Actinomyces viscosus, and Streptococcus mutans. Based on antiplaque activity Juglans regia, it is suggested as one of the potential products for improving oral hygiene and dental health [127].

\subsection{Asparagus racemosus Willd (Satavari)}

Asparagus racemosus grows up to two meters tall, favors to grow on rocky soil with an altitude range of 1300-1400 m, and belongs to the Liliaceae family. It is commonly known as satavari. It is distributed throughout Asia, Australia, and Africa at low altitudes in tropical and shade climates. In India, Asparagus racemosus is used for various medicinal uses. Root parts of Asparagus racemosus can be used as a drug to cure diseases [17]. Now, these days, oral infectious diseases such as periodontal disease and dental caries are more of the main health problems globally. The study on the chemical composition of Asparagus racemosus essential oil was found to have 55 compounds. The essential oil extracted from aerial parts of Asparagus racemosus using the solvent extraction method, and further composition was analyzed by GC-MS. The main chemical components of essential oil are myrtanol (13.72\%), borneol (26.40\%), 2-ethylhexanol (1.76\%), pinocarveol $(2.37 \%)$, perillaldehyde $(8.97 \%)$, hexanal $(1.34 \%)$, furfural $(1.17 \%)$, decanoic acid $(4.19 \%)$, undecanoic acid (2.72\%), 4-(1-hydroxyethyl) benzaldehyde (1.55\%), camphor (3.335), 6,10,14-trimethyl pentadecanone (1.71\%), and (E)-4-hexadecen-6-yne (2.25\%) [47,48]. In vitro study on the 
extract of Asparagus racemosus shows antibacterial activity against caries causing oral pathogens Streptococcus mutans and Lactobacillus acidophilus [50].

\subsection{Juniperus communis $L$.}

Juniperus communis, commonly known as Juniper and Aaraar, is an evergreen aromatic shrub that belongs to the Cupressaceae family. It is distributed throughout cold and temperate regions of the Himalayan regions, mainly in Kashmir, Bhutan, and western Tibet, at an altitude of 2743 to $4572 \mathrm{~m}$ above sea level. Four species of genus Juniperus: Juniperus indica Bertol., Juniperus recurve Buch.-Ham. ex D. Don., Juniperus squamata Buch.-Ham. ex D. Don., and Juniperus communis L., were reported from Uttarakhand [128]. The bark part of Juniperus procera Hochst. ex Endl. is used to cure toothache in Ethiopia [129]. A recent study reported that a correlation is found between the quantity of phosphate and calcium ions in the Juniperus communis toothpaste. The toothpaste of J. communis was linked with high phosphate concentration due to the presence of pyrophosphate in its composition. The antioxidant effect of Juniperus communis is reported to prevent the biological system from oxidative damage caused by a reactive form of oxygen $\left(\mathrm{H}_{2} \mathrm{O}_{2}\right.$ and $\left.\mathrm{OH}\right)$ [130]. The study on the species of Juniperus communis reported the plant to have potential use in dental practice. The plant can be used as an effective antimicrobial agent due to the availability of terpene in essential oil composition [131].

The essential oil of Juniperus indica and Juniperus communis was extracted from berries and leaves by using the hydrodistillation method. The chemical composition in essential oil is analyzed using GC-MS. In Juniperus communis, the essential oils of leaves and berries, a total of 48 and 59 compounds were reported with a yield of $91.24 \%$ and $87.02 \%$, and in Juniperus indica, 36 and 39 compounds were reported with a yield of $91.50 \%$ and $93.77 \%$. The main compounds reported in berries and leaves of Juniperus indica are terpinen-4-ol (16.11\% and $23.61 \%), \alpha$-pinene $(6.34 \%$ and $8.82 \%)$, sabinene (27.75 and $23.17 \%)$, and $\gamma$-terpinene $(6.05 \%$ and $6.58 \%)$. In contrast, the main components of Juniperus communis leaves and berries were $\alpha$-pinene ( $35.35 \%$ and $10.78 \%)$, limonene $(23.75 \%$ and $15.06 \%)$, and terpinen-4ol $(0.93 \%$ and $8.76 \%)$ [128]. Antibacterial in vivo study on essential oil of Juniperus communis reported moderate to high activity against pathogen bacteria Staphylococcus aureus (cause of dental implant infections), Escherichia coli, Hafina alvei for concentration $5 \mathrm{mg} / \mathrm{mL}$ with a zone of inhibition 10-35 mm [102,132].

\subsection{Melaleuca alternifolia (Maiden and Betche) Cheel}

Melaleuca alternifolia (tea tree) is a tall shrub that normally grows 4 to $6 \mathrm{~m}$ in height and belongs to the Myrtaceae family. The species of the Melaleuca genus are distributed commonly in Australia, mostly at an altitude range of $300 \mathrm{~m}$ [51]. M. alternifolia is also reported in the Nilgiris district of Tamil Nadu, India [133]. Melaleuca alternifolia is used by traditional Australian medicine. For chemical compounds such as cineol, terpinen-4-ol, terpinolene, cymene, limonene, sabinene, terpinene, pinene viridiorol, and globulol, their chemical compositions include mostly terpenic compounds [52]. Melaleuca alternifolia is used for periodontitis [54], bad breath, relief from bleeding gums and plaque [55]. The Melaleuca alternifolia essential oil is extracted from leaves and terminal branches by using the steam distillation method. The main chemical component present in the essential oil extract of leaves were terpinolene, terpinen-4-ol, cineol, limonene, cymene, terpinene, pinene, sabinene, viridiflorol, and viridiflorol. Its chemical composition includes mostly terpenic compounds [52]. Recently, in vivo trials conducted on melaleuca gel were reported to have an inhibitory effect on bacterial growth, causing dental caries, periodontitis, dental plaque, and gingivitis. A study found that during experimental oral candidiasis, mice are protected by terpin-4-ol, which is one of the main chemical constituents present in Melaleuca alternifolia essential oil [134]. Melaleuca alternifolia Cheel is used in Australian traditional medicine. The essential oil extracted from leaves exhibits chemical compounds such as terpinene, terpinolene, terpinen-4-ol, cymene, cineol, limonene, pinene, sabinene, viridiflorol, and globulol. Its chemical composition exhibits mostly terpenic composites $[135,136]$. 


\subsection{Acacia nilotica (L.) Delile}

Acacia nilotica is an evergreen tree commonly known as Babul that belongs to the Leguminosae family. Gamble (1918), in his "Flora of Madras Presidency" book, has documented more than 40 species of Acacia genus from India. It is distributed among various countries such as India, Saudi Arabia, Oman, Iran, Israel, Nepal, Pakistan, Angola, Egypt, Mali, Ethiopia, Ghana, Kenya, Libya, Malawi, Botswana, Mozambique, Kenya Niger, Senegal, Somalia, Nigeria, South Africa, Tanzania, Uganda, Zimbabwe, and Sudan [56]. The essential oil is extracted using the hydrodistillation method, and GC-FID and GC/MS were used for the analysis of the constituents of essential oil. The amount of essential oil obtained from the bark of Acacia nilotica was $0.08 \% \mathrm{v} / \mathrm{w}$. About 36 chemical compounds were reported in the essential oil of A. nilotica, out of which limonene $(15.3 \%)$ and menthol $(34.9 \%)$ are among the two important compounds. Monoterpenoid compounds $(69.6 \%)$ are predominant in the oil as compared to sesquiterpenes (19.4\%). The oil consists of the monoterpenoids limonene (15.3\%) and menthol (34.9\%) in higher amounts, followed by carvacrol (4.1\%) and $\alpha$-curcumene (6.9\%) were present in small quantities [57]. Different alkaloids are present in the extract of Acacia nilotica, such as dimethyltryptamine, tryptamines and $N$-methyltryptamine. Using the agar diffusion technique, the antibacterial activity of stem and bark extract of Acacia nilotica was studied against oral pathogens: Staphylococcus aureus, Streptococcus viridans, Escherichia coli, Shigella sonnei, and Bacillus subtilis, and the result shows minimum inhibitory concentration (MIC) of bark and stem extract ranged in between 30 and $50 \mathrm{mg} / \mathrm{mL}$ [137]. The stem and bark part of Acacia nilotica can be used in toothpaste and tooth cleaner. The paste of stem and bark of Acacia nilotica is used to make the gum strong or to cure gum bleeding. The extract prepared from the stem and bark of Acacia nilotica is used in gargling to cure throat-related problems and is also helpful in relieving toothache. Its branches were also used for cleaning teeth [58]. In the traditional system of medicine, the combination of the bark of mango and the bark of Acacia nilotica taken in equal quantity $(\sim 6 \mathrm{~g})$ boiled in water (approximately $750 \mathrm{~mL}$ ) for half an hour and filtered is used for gargling and is helpful to cure mouth ulcers. The extract of Acacia nilotica provides relief from toothache, and branches are used for cleaning teeth [58]. In addition, the decoction prepared from the leaves and bark of Acacia nilotica in combination with the bark of Terminalia chebula (hardh) is used to treat mouth ulcers [56] and to cure sore throat [60].

\subsection{Quercus infectoria G. Oilvier}

Quercus infectoria, a small tree also known by the name of the Aleppo oak, is a species of oak that belongs to the family Fagaceae. It is native to Greece, Iran, Turkey, Persia, Cyprus, Syria, Nepal, and Asia Minor. It is distributed among some parts of India (Garhwal Himalayas). It is also known as "baloot" in Iran and is a frequently used medicinal plant. Manjakani is another name used in Malaysia for Quercus infectoria [61]. The main chemical constituents present in galls of Quercus infectoria were 50-70\% tannins [138], sugar [62], gallic acid (2-4\%), and ellagic acid [61]. Numerous tannins have been reported to have antibacterial efficacy against different strains of bacteria [139-141]. The essential oil from the leaves of Quercus infectoria was extracted by steam distillation method by using a Clevenger apparatus. The results show a $0.2 \%$ yield of essential oil extracted from leaves of Quercus infectoria [61]. Quercus infectoria bears galls, which are used by the traditional system of medicine since ancient times in Asia [62]. The galls occur on the branches of this tree due to the deposition of eggs by Cynips gallae tinctoriae (gall wasp) [142]. In India, galls of Quercus infectoria is used by the traditional system of medicine as a constituent of toothpaste or toothpowder for the treatment of oral cavity and gum infections. From recent studies in past years, it has been reported that galls possess antiviral, antifungal, antibacterial properties and are used for the treatment of gingivitis and toothache [62]. In the traditional system of medicine, Quercus infectoria is used as a tonic for teeth and gums, and for the treatment of dental cavities due to its antimicrobial property [143]. The acetone and methanol extract of the gall of Quercus infectoria in agar-well diffusion assay exhibited 
activity against oral pathogens such as Fusobacterium nucleatum ATCC 25586, Streptococcus mutans ATCC 25175, Streptococcus salivarius ATCC 13419, and Porphyromonas gingivalis ATCC 33277. The MIC ranged between 0.16 and $0.63 \mathrm{mg} / \mathrm{mL}$, and the most susceptible bacteria is $S$. salivarius, which suggested that oak extract might be used in contradiction of periodontitis etiological agents and dental caries [62].

\subsection{Artemisia dracunculus L.}

Artemisia dracunculus belongs to the family Compositae and is a perennial herb, also known by the name of French tarragon and estragon. The plant grows in wild habitat throughout central Europe and Asia and is widely cultivated due to the popularity of tarragon-vinegar-based dressings and sauces. Artemisia possesses bioactivity due to the occurrence of numerous active ingredients (essential oil components) and secondary metabolites and has widespread pharmacological activities [144]. The extracts obtained from $A$. dracunculus have antiseptic, stimulant, antibacterial, and antifungal activities [145]. The essential oil is produced in glandular hairs and oil canals of Artemisia dracunculus, having a gentle, spicy scent. The essential oil mainly consists $\beta$-pineneocimene, methyl chavicol (about 65\%), camphene, sabinene, limonene, and menthol. The essential oil composition of Artemisia dracunculus has been intensively examined, and the following compounds were identified as major chemical compounds (approximately $\geq 10 \%$ ): estragol (methyl chavicol), $\alpha$-terpinolene, (E)-anethole, capillene, methyl eugenol, (Z)-artemidin, elemicin5-phenyl,1,3-pentadiyne, (E)- $\alpha$-ocimene, $(Z)$ - $\beta$-ocimene limonene, pulegone, $(E)$ $\beta$-ocimene, $\alpha$-phellandrene, $\alpha$-pinene, isoelemicin, $\beta$-phelland-rene, acenaphthene, and hinokitiol [63]. From the aerial parts of Artemisia dracunculus, essential oil is obtained using the hydrodistillation method, and the GC-MS method is used for the identification of chemical constituents present in essential oil [61]. In Tajikistan, aerial parts from the $A$. dracunculus were collected, and about 45 compounds representing about $99.8 \%$ of the total fraction of oil were identified. In Artemisia dracunculus, limonene (7.8\%), sabinene (29.1\%), (Z)-artemidinn (4.9\%), estragole $(24.6 \%),(\mathrm{E})-\beta$-ocimene $(4.0 \%)$, and myrcene $(4.8 \%)$ are present in higher amounts in the aerial parts [63]. Artemisia dracunculus has been used as a folk remedy since ancient times. Ibn al-Baitar, Avicenna, Al-Beruni, Gelenus, and others have reported the medicinal properties of Artemisia dracunculus in their research studies. Avicenna reported that tarragon grass (fresh) is useful for bad breath and bleeding gums [63].

\subsection{Streblus asper Lour}

Streblus asper belongs to the Moraceae family, is a small tree, and is commonly known by numerous names such as barinka, koi, berrikka, rudi, serut, Siamese rough bush, sheora, and most commonly, it is known by the name of "toothbrush tree". It is widely distributed among several Asian countries, such as Sri Lanka, Southern China, India, the Philippines, Malaysia, and Thailand [65]. Analysis of the compounds present in the aerial parts of Streblus asper is performed by and HPTLC (high-performance thin-layer chromatography), TLC (thin-layer chromatography) method, and the following chemical compounds were identified in the stem part: $\alpha$-amyrin acetate, $\beta$-sitosterol, strebloside, lupeol acetate, diol, sioraside, $\alpha$-amyrin, mansonin, (7'S, 8'S)-threo-streblusol B, streblusquinone, (8R, 8'R)streblusol D, (7'S, 8'S)-trans-streblusol A, streblusol E, and 8'R-streblusol C. From the aerial bark: $n$-triacontane, $\beta$-sitosterol, stigmasterol, tetraiacontan-3-one, oleanolic acid, and botulin, and from heartwood: flavonoids and lignans were reported [65]. Different plant parts of Streblus asper were used for the treatment of different ailments in folk medicines. The extract from Streblus asper stem bark is used to provide relief from toothache and has anti-gingivitic properties. The branch part of Streblus asper is used as a toothbrush for gum strengthening. The milky juice obtained from Streblus asper bark shows an antiseptic property that is useful as anti-infectious gargles [65]. A study reported antibacterial activity in leaf extract of Streblus asper is helpful in controlling dental caries [146]. In vivo study was carried out on 30 human cases, and the results revealed that one minute rinse with 
about $20 \mathrm{~mL}$ of Streblus asper extract (SAE) of concentration $80 \mathrm{mg} / \mathrm{mL}$ can considerably decrease the number of Streptococcus mutans colonies compared with water (distilled) and there is no change in the buffer capacity and salivary $\mathrm{pH}$ [147]. The extract of Streblus asper is also effective against the growth of Porphyromonas gingivalis and Aggregatibacter actinomycetemcomitans colonies [146]. Streblus asper leaf extract has a positive effect during subgingival irrigation in chronic periodontitis [148].

\subsection{Cichorium intybus $L$.}

Cichorium intybus L. belongs to the Compositae family and is a perennial, woody, herbaceous plant commonly known as chichory [149]. Distributed among different parts of the world, likewise as in Afghanistan, India, Bulgaria, Italy, Morocco, Iran, Serbia, Jordan, and Poland [68]. Essential oil is extracted from aerial parts of Cichorium intybus, and the hydrodistillation and liquid-liquid extraction methods (a two-step process) are used. For extraction of volatile oil, pentane as solvent is used. The concentrated extract is yellow in color and has a strong smell. For the extraction and identification of constituents present in the essential oil combination of GC-FID and GC-MS methods are used, and 20 chemical compounds were identified from the aerial parts of Cichorium intybus. The major components present in oil are: cinnamic aldehyde $(12.4 \%)$, carvacrol $(50.1 \%)$, camphor $(4.4 \%)$, carvone $(4.1 \%)$, linalool $(3.9 \%)$, terpineol $(2.1 \%)$, and thymol $(13.3 \%)$ [69]. The major compound present in the methanolic extract of Cichorium intybus is chicoric acid. Terpenoids constitute the minor portion of Cichorium intybus, while aliphatic composites and their byproducts constitute the major fraction. Saccharides, flavonoids, essential oils, methoxy-coumarin cichorine, and anthocyanins present in the flower of Cichorium intybus provide blue color to the petals $[69,150]$. The compounds present in the essential oil of Cichorium intybus (adapted from [150]) are octane, n-nonanal, 2-Pentyl furan, octen-3-ol, allo-aromadendrene, acetaldehyde, (2E,4E)-heptadienal, (2E,4E)-decadienal, camphor, (2E)-nonen-1-al, (2E,6Z)-nonadienal, $n$-decanal, $n$-decanol, (2E,4E)-nonadienal, (2E,4Z)-decadienal, (E)-caryophyllene, $n$-tridecane, $(\mathrm{E})-\beta$-farnesene, $\beta$-elemene, benzene, (2E)-tridecanol, $n$-octadecanol, (5E,9E)-farnesyl acetone, (E)-2-hexylcinnamaldehyde, $n$ nonadecane, $n$-eicosane, $n$-heneicosane, and octadecane [71]. In Cuetzalan, the latex obtained from C. inhybtus is used to break up molars (with cavities) by setting a drop of latex directly on the tooth. Low molecular mass (LMM) extract of Cichorium intybus var. Silvestre (red chicory) is reported to prevent virulence-linked properties of bacterial species (oral pathogens) such as Prevotella intermedia, actinomyces, and Streptococcus mutans, which are responsible for biofilm formation (plaque) and pathogens causing gingivitis and tooth decay. Succinic and quinic acid are most effective against oral pathogens that are mainly responsible for biofilm formation (by interfering with their development or promotion of commotion). From recent in vivo studies, it is reported that one or few other compounds may control plaque formation, which is responsible for the development of gingivitis and dental caries [71].

\subsection{Vitex negundo Linn. (Nirgundi)}

Vitex negundo L. belongs to the Verbenaceae family. In India, it is locally known by the name "Nirgundi" and is a valuable medicinal plant. Vitex negundo is a woody, aromatic, erect, deciduous shrub, growing up to a height of 2-5 m. It flourishes best in moist places and along water routes in wilds at an altitude of $1500 \mathrm{~m}$ above sea level. V. nigundo is distributed in India, Madagascar, Thailand, Sri Lanka, Afghanistan, Pakistan, Eastern Africa, and Malaysia [72]. GC-MS method is employed to examine the chemical compounds of essential oil obtained from the dried fruits, flowers, and leaves of Vitex negundo. The main components present in the essential oil were sesquiterpenes (44.41\%) comprised of caryophyllene oxide (11.33\%), eremophilene (12.76\%), caryophyllene $(18.27 \%), \beta$-bisabolene $(0.94 \%), \alpha$-bergamotene $(0.53 \%)$ and humulene $(0.58 \%)$. The monoterpenes $(19.25 \%)$ in the oil include $1(R)-\alpha$-pinene $(0.21 \%)$ and sabinene $(19.04 \%)$. There are four types of esters present in the oil, named $\beta$-terpinyl acetate $(8.99 \%)$, nerol 
acetate $(1.18 \%)$, linalyl formate $(3.72 \%)$, and $0.88 \%$ of geranyl acetate. $(-)$-terpinen-4-ol $(2.82 \%)$, menthol $(1.44 \%)$, and linalool $(4.27 \%)$ are three main alcohols found in the essential oil. $o$-cymene $(5.90 \%)$ is the aromatic compound, and menthone $(4.96 \%)$ is the ketone found in the essential oil of Vitex negundo. A total of $0.40 \%$ of eucalyptol is also present in the oil [151]. The various chemical compounds present in essential oil obtained from dried fruits, leaves, and flowers are epoxide, $\alpha$-cedrene, $\delta$-guaiene, ethyl-hexadecenoate, $\alpha$-selinene, $\beta$-caryophyllene (16.59\%), caryophyllene epoxide, $\beta$-selinene, germacrene, hexadecenoic acid, (E)-nerolidol, guaia-3,7-dienecaryophyllene epoxide, p-cymene, valencene, viridiflorol (19.55\%), 1-oceten-3-ol (1.59\%), germacren-4-ol, sabinene $(12.07 \%), \gamma$-terpinene $(2.21 \%)$, caryophyllene oxide (1.75\%), 4-terpineol (9.65\%), 1-oceten-3-ol (1.59\%), and globulol $(1.05 \%)$ [74]. The extract obtained from the stem bark and leaves of Vitex negundo is very useful against toothache, throat pain, mouth ulcers [152]. The decoction of Vitex negundo leaves is used for gargling and for the treatment of sores [76].

\subsection{Rosmarinus officinalis $L$.}

Rosmarinus officinalis L. belongs to the family Lamiaceae, is commonly known as rosemary, and is a medicinal plant. The plant is indigenous to Asia and South Europe, also cultivated in some parts of India and the Mediterranean basin [77]. Rosmarinus officinalis is also known as rusmari (Sanskrit), rosemarijin (dutch), gulmehendi (Hindi). The essential oil extracted from the leaves of Rosmarinus officinalis and the identification of the constituents present in the oil is performed by GC technique and HPLC (high-performance liquid chromatography), that has revealed high contents of volatile oil [78]. The principal constituents present in rosemary oil (from leaves) are: borneol (1.5-5.0\%), camphor (5-31\%), limonene (1.5-5.0\%), camphene (2.5-12.0\%), pinene (9-26\%), 1,8-cineol (15-55\%), pinene (2.0-9.0\%), myrcene (0.9-4.5\%), verbenone (2.2-11.1\%), and caryophyllene (1.8-5.1\%) [79]. The chief constituent present in essential oil camphor has an antibiofilm property, which helps to prevent plaque formation [79]. Recently, in vivo study reported a reduction in biofilm by rosemary essential oil and recommended its use in new anti-caries treatment protocols [80].

\subsection{Embelia ribes Burm. $f$.}

Embelia ribes Burm.f. belongs to the Primulaceae family and is commonly known as vaibidang. False black pepper is an endangered climbing shrub that generally occurs in the evergreen to semi-evergreen forests of China, India, Sri Lanka, and Malaysia [81]. In India, Embelia ribes grows at a $1500 \mathrm{~m}$ altitude range [153]. Phyto constituents present in Embelia ribes are embelin, embolic acid, and rapanone [81]. The berries of Embelia ribes comprise benzoquinone derivatives such vilangin and embelin (2,5-dihydroxy-3-undecyl2,5-cyclohexadiene-1,4-benzoquinone) [83]. The antimicrobial efficacy of the Embelia ribes is due to the occurrence of secondary metabolites such as flavonoids, lectins, polyphenols, and alkaloids [153]. Embelin shows antibacterial properties against Streptococcus mutans and Streptococcus sanguis (Gram-positive bacteria) present in the mouth, responsible for biofilm formation. From Embelia ribes, the extraction of embelin was conducted according to principles of Indian Herbal Pharmacopoeia (2002). From Embelia ribes plant, $100 \mathrm{~g}$ of powdered berries were extracted in Soxhlet extraction for about $6 \mathrm{~h}$ using $\mathrm{n}$-hexane as a solvent then the extract is evaporated on a rotator and is again crystallized using chloroform and ethanol, and the characterization of the extract is performed by using differential scanning calorimeter (DSC), X-ray diffraction, ultraviolet-visible spectroscopy (UV-visible), Fourier-transform infrared spectroscopy (FTIR), nuclear magnetic resonance spectroscopy (NMR), and thermo gravimetric analysis (TGA) analysis method [82]. The fruits of Embelia ribes were used in the ayurvedic system of medicine for medicinal purposes. In India, due to its antibacterial properties, it is traditionally employed [81]. Paste prepared from Embelia ribes is used as a mouthwash and is also effective against dental cavities [85]. 


\subsection{Spilanthes Species}

Genus Spilanthes belongs to the Compositae family and is distributed among the tropical regions of the world. In India, Spilanthes genus is characterized by the presence of six species: Spilanthes uliginosa Sw, Spilanthes calva DC, Spilanthes radicans Jacq., Spilanthes paniculata DC., Spilanthes oleracea, and Spilanthes ciliate Kunth. In the tropical and subtropical areas around the world, these plants (Spilanthes spp.) were used frequently in traditional medicine. The main use of Spilanthes spp. in the field of medicine is to treat toothache in which the leaves and fresh flowers were chewed or to relieve pain it is placed onto tooth cavities. In India, the juice of the Spilanthes acmella flower is effective in curing oral ulcers [86]. The main phytochemicals present in the Spilanthes genus are unsaturated and saturated alkyl ketones, acetylenes, hydrocarbons, terpenoids, alkamides, alkaloids, lactones, coumarins, and flavonoids. These constituents are responsible for the pharmacological activity of Spilanthes species [86]. Essential oils of only a few species have been explored. GC and GC-MS methods were used for the analysis of essential oils from Spilanthes species. The chemical composition of the essential oil is variable, indicating the presence of many chemotypes in it [86]. Supercritical $\left(\mathrm{CO}_{2}\right)$ and SDS (simultaneous distillation extraction) from flowers, leaves, and stems of Spilanthes americana results in the separation of volatile compounds, which include cadinene (anisomeric hydrocarbon), sesquiterpenes ( $\alpha$-caryophyllene, $\alpha$-and $\beta$-bisabolene, $\beta$-caryophyllene), $\mathrm{N}$-(isobutyl)-6Z,8E-decadienamide, $\mathrm{N}$-(2-methylbutyl)-2E,6Z,8E-de catrienamide, and $\mathrm{N}$-(2phenylethyl)-2E,6Z,8E-decatrienamide), and various oxygenated compounds were isolated by SDE method. Supercritical fluid extraction (SFE) extracts from the stems of Spilanthes americana are found rich $(>40 \%)$ in sesquiterpenes, while flowers and leaves are rich in nitrogenated (43\% and $27 \%$ ) and oxygenated (36\% and $23 \%$ ) compounds. About seven chemical components from the essential oil were identified, include caryophyllene oxide, myrcene, sesquiterpene, limonene, and caryophyllene [86]. The flower part of Spilanthes uliginosa is used in the treatment of gum infection and sore throat [91]. The flower and leaf part of Spilanthes acmella L. is used for toothache and throat complaints [89]. The aerial parts of Spilanthes filicaulis Jacq. were useful for the treatment of tooth decay [90]. Leaves of Spilanthes calva is useful for gingivitis, throat complaints parts, and for toothache, teeth were brushed with flowers [92]. The decoction of leaves and flowers from Spilanthes oleracea is used for toothache and throat complaints [88]. The whole plant of Spilanthes filicaulis is effective in curing toothache. Parts used [154]. The flowers of Spilanthes paniculate were used for the treatment of toothache, tooth infections by chewing flowers followed by rinsing with water [155].

\subsection{Nigella sativa $L$.}

Nigella sativa, commonly known as black seed or kalonji, is well known for its health benefits [95]. Distributed among the Middle East, southern European continent, and North Africa, and in India, it is cultivated in the areas of Bengal, Bihar, Gangetic plains, Himachal Pradesh, Assam, Maharashtra, and Punjab [93]. The essential oil of N. sativa seed is extracted using solvent extraction method and SFE (supercritical fluid extraction), and the chemical composition of essential oil is analyzed using GC-MS. Main compound reported were carvacrol $(5.8-11.6 \%)$, longifolene (1.0-8.0\%), $\rho$-cymene (7.1-15.5\%), t-anethole (0.25-2.3\%), 4-terpineol (2-6.6\%) and thymoquinone (27.8-57.0\%) [94]. Thymoquinone $\left(\mathrm{C}_{10} \mathrm{H}_{12} \mathrm{O}_{2}\right)$ is recognized as the most important bioactive compound found in $N$. sativa oil with medicinal properties such as antioxidant, anti-inflammatory, antimicrobial, analgesic, anticarcinogenic and antihypertensive [96]. A recent study reported that thymoquinone could play an important role in the treatment and prevention of periodontal diseases. In a clinical trial (RCTs), $0.2 \%$ thymoquinone gel shows a significant decrease in GI (gingival index), PPD (probing pocket depth), and PI (plaque index) levels and an increase in GCF (gingival crevicular fluid)-ALP (alkaline phosphatase) levels. They also show sensitivity against Prevotella intermedia, Porphyromonas gingivalis, and Aggregatibacter actinomycetemcomitans [95]. 
Role of various medicinal plants discussed in the current review against various oral pathologies is presented in Table 2.

\section{Antioxidant Extracts from Medicinal Plants in Oral Health: A Clinical Trial Perspective}

The antigingivitic and antiplaque effect of fluoridated dentifrice and $4 \%$ Ocimum sanctum extract was studied in a triple blinded randomized clinical trial (RCT) among 14-15year-old school children, and reduction in dental plaque $(p=0.01)$ and gingivitis $(p=0.001)$ was observed maximum in $4 \%$ tulsi extracts in comparison with the fluoridated dentifrice group [156]. In triple blinded RCT, the effect of phenolic mouth wash and Salvadora persica oral rinse was compared among girls 18-22-year-old for six months and were found to be equally effective as no statistically significant difference was observed in all the examination phases between the mean gingival and plaque scores of two groups [157]. The effect of Eucalyptus globulus extract added as an ingredient in herbal product (tooth and gums tonic) was compared with chlorhexidine $\mathrm{M}$ gel in double-blind RCT and showed a decrease in mean gingival and plaque value at different intervals. It was observed to be equally effective in comparison to chlorohexidine with no statistically significant difference $(p=0.001)$ [158].

In double-blinded RCT, the efficacy of $2.5 \% \mathrm{NaOCl}$ is compared to neem as root canal irrigants on amount of endotoxin and intensity of pain after root canal treatment in mandibular molars with necrotic pulps. It is observed that the neem group has lower mean pain scores compared to the $2.5 \% \mathrm{NaOCl}$ group and shows no significant difference except $24 \mathrm{~h}$ following instrumentation $(p=0.012)$. Endotoxin levels were reduced by $18 \%$ in neem group and $8 \%$ in $\mathrm{NaOCl}$ group in comparison to pre-instrumentation samples $(p<0.001)$ [159]. In a recent study (RCT), the efficacy of Juglans regia on developing dental plaque was examined among 16-30 years age group, and the result shows $2 \%$ ether extract (bark) with maximum plaque inhibition of $32.12 \%$ as compared to other preparations $3 \%$ ether extract $31.56 \%$, petroleum ether extract $2-17.62 \%$ and $3-19.45 \%$, and aqueous solution $2-30.32 \%$ and propylene glycol as a solvent in preparations shows $7.88 \%$ of antiplaque activity [46].

Recently RCT is conducted on 30 patients to evaluate the efficacy of locally delivered $5 \%$ tea tree oil (TTO) gel adjunctive to scaling root planning (SRP) as an intrapacket application for stage 2 periodontitis treatment, and significant difference and improvement was observed in biochemical and clinical parameters at $p<0.001$ in both groups. The test group treated with 5\% TTO gel and SRP is found to be more effective in treating stage 2 periodontitis in comparison with the control group treated with SRP only [160]. Table 3 presents examples of various clinical trials showing positive effect of medicinal plant extracts in maintaining oral health. 
Table 3. Clinical trials on the effect of antioxidant extracts from medicinal plants in oral health.

\begin{tabular}{|c|c|c|c|c|c|}
\hline Title & Extract and Dose Used & Objective & Location & Main Finding of the Study & Reference \\
\hline $\begin{array}{l}\text { Comparative evaluation of efficacy of } 4 \% \text { tulsi extract } \\
\text { fluoridated and placebo dentifrices against gingivitis and } \\
\text { plaque: a triple-blind RCT }\end{array}$ & $\begin{array}{l}4 \% \text { ethanolic extract } \\
\text { (tulsi dry leaves), Dose: } \\
\text { twice/day (21 days), } \\
\text { Application:Toothpaste }\end{array}$ & $\begin{array}{l}\text { To assess and compare the antigingivitis and antiplaque } \\
\text { effect of fluoridated, placebo dentifrice (PD) and } 4 \% \\
\text { tulsi leaf extract dentifrice among } 14-15 \text {-year-old school } \\
\text { children. }\end{array}$ & $\begin{array}{l}\text { Davangere city, } \\
\text { India }\end{array}$ & $\begin{array}{l}\text { Maximum reduction in dental plaque }(p=0.01) \text { and } \\
\text { gingivitis score }(p=0.001) \text { in } 4 \% \text { tulsi dentifrice } \\
\text { compared to PD. }\end{array}$ & [156] \\
\hline $\begin{array}{l}\text { Comparative clinical effects of Salvadora Persica oral rinse and } \\
\text { phenolic commercial mouth wash on human oral health: a } \\
\text { triple-blind RCT }\end{array}$ & $\begin{array}{l}\text { Salvadora persica oral } \\
\text { rinse } 50 \% \text { conc., Dose: } \\
15 \mathrm{~mL} \text { twice/day ( } 6 \\
\text { months), Application: } \\
\text { gargle, mouthwash }\end{array}$ & $\begin{array}{l}\text { To compare the clinical effects of Salvadora persica oral } \\
\text { rinse and commercial phenolic mouth wash on oral } \\
\text { health status of socially deprived madrasa girls 18-22 } \\
\text { years old. }\end{array}$ & $\begin{array}{l}\text { Multan city, } \\
\text { Pakistan }\end{array}$ & $\begin{array}{l}\text { With no statistical difference in gignival and plaque } \\
\text { scores, Salvadora persica oral rinse is equally } \\
\text { effective as phenolic mouth wash. }\end{array}$ & [157] \\
\hline $\begin{array}{l}\text { Antiplaque effect of hiora-GA gel, spirogyl gum paint, and } \\
\text { tooth and gums tonic in comparison with chlorhexidine M gel: } \\
\text { a double-blind RCT }\end{array}$ & $\begin{array}{l}\text { Eucalyptus globulus } \\
\text { extract (tooth and gums } \\
\text { tonic), Dose: twice/day } \\
\text { (90 days), Application: } \\
\text { gel directly applied on } \\
\text { tooth surface }\end{array}$ & $\begin{array}{l}\text { To compare the efficacy of three different herbal } \\
\text { products in gingival inflammation, bacterial count, and } \\
\text { reducing plaque in comparison with chlorhexidine } \mathrm{M} \\
\text { gel among participants with moderate to severe } \\
\text { periodontitis. }\end{array}$ & $\begin{array}{l}\text { Osmania Dental } \\
\text { College and } \\
\text { Hospital, } \\
\text { Hyderabad, India }\end{array}$ & $\begin{array}{l}\text { The mean gignival and plaque scores were } \\
\text { decreased at different intervals, and no significant } \\
\text { difference is oserved in efficacy of gel compared to } \\
\text { chlorhexidine. }\end{array}$ & [158] \\
\hline $\begin{array}{l}\text { Effect of } 2.5 \% \text { sodium hypochlorite versus neem as root canal } \\
\text { irfigants on the intensity of post-operative pain and the amount } \\
\text { of endotoxins in mandibular molars with necrotic pulps: RCT }\end{array}$ & $\begin{array}{l}\text { Neem (root canal } \\
\text { irrigant), Dose: one } \\
\text { time each followed by } \\
\text { two root canal } \\
\text { treatments }\end{array}$ & $\begin{array}{l}\text { To assess the efficacy of } 2.5 \% \mathrm{NaOCl} \text { versus neem as } \\
\text { root canal irrigants on amount of endotoxins and } \\
\text { intensity of post-operative pain following root canal } \\
\text { treatment of mandibular molars with necrotic pulps }\end{array}$ & $\begin{array}{l}\text { Cairo University, } \\
\text { Egypt }\end{array}$ & $\begin{array}{l}\text { In neem group, mean pain scores were lower as } \\
\text { compared to } 2.5 \% \mathrm{NaOCl} \text { and neem group reduced } \\
\text { endotoxin level by } 18 \% \text { in comparison with } \\
\text { pre-instrumentation samples. }\end{array}$ & [159] \\
\hline \multirow{3}{*}{$\begin{array}{l}\text { Clinical effect of Juglans regia on the developing dental } \\
\text { plaque: RCT }\end{array}$} & $2 \%$ ether extract (bark), & \multirow{3}{*}{$\begin{array}{l}\text { To assess the clinical effect of } 2 \% \text { aqueous extract, } 2 \% \\
\text { and } 3 \% \text { concentration of ether fractions in propylene } \\
\text { glycol and petrol-ether extract of bark of Juglans regia } \\
\text { against developing plaque }\end{array}$} & \multirow{3}{*}{$\begin{array}{l}\text { Faculty of Dental } \\
\text { Sciences, C. S. M. } \\
\text { Medical } \\
\text { University, } \\
\text { Lucknow, India }\end{array}$} & \multirow{3}{*}{$\begin{array}{l}2 \% \text { ether extract of Juglans regia showed maximum } \\
\text { antiplaque activity of } 32.12 \%(p<0.001)\end{array}$} & \multirow{3}{*}{ [46] } \\
\hline & $\begin{array}{l}\text { Dose: twice/day } \\
\quad(3 \text { days), }\end{array}$ & & & & \\
\hline & $\begin{array}{l}\text { Application: extract } \\
\text { directly applied on } \\
\text { tooth surface }\end{array}$ & & & & \\
\hline \multirow{2}{*}{$\begin{array}{l}\text { Intrapocket application of Melaleuca alternifolia tea tree oil (TTO) } \\
\text { gel in the treatment of stage II periodontitis: a phase } 2 \\
\text { clinical trial }\end{array}$} & \multirow{2}{*}{$\begin{array}{l}5 \% \text { TTO gel and SRP, } \\
\text { Dose: } 0.5 \mathrm{~mL} \text { gel, } \\
\text { Application: gel } \\
\text { directly applied on } \\
\text { dental pockets }\end{array}$} & \multirow[t]{2}{*}{$\begin{array}{l}\text { To assess biochemically and clinical the effect of } \\
\text { intrapocket application of TTO gel and scaling and root } \\
\text { planing (SRP) in the treatment of stage II periodontitis } \\
\text { and to correlate biochemical levels with clinical response }\end{array}$} & $\begin{array}{l}\text { Faculty of } \\
\text { Dentistry, } \\
\text { Alexandria } \\
\text { University }\end{array}$ & \multirow[t]{2}{*}{$\begin{array}{l}\text { TTO gel adjunctive to SRP is found to be effective in } \\
\text { treatment of stage II periodontitis. }\end{array}$} & \multirow[t]{2}{*}{ [160] } \\
\hline & & & Alexandria, Egypt & & \\
\hline \multirow{2}{*}{$\begin{array}{l}\text { Effect of a Toothpaste/Mouthwash Containing Carica papaya } \\
\text { Leaf Extract on Interdental Gingival Bleeding: A Randomized } \\
\text { Controlled Trial }\end{array}$} & $\begin{array}{c}\text { Carica papaya leaf } \\
\text { extract }\end{array}$ & \multirow{2}{*}{$\begin{array}{l}\text { To study the comapartive effectiveness of dentifrice } \\
\text { having papaya leaf extract to a commercially available } \\
\text { sodium lauryl sulfate-free enzyme-containing dentifrice } \\
\text { in management of gingival bleeding }\end{array}$} & \multirow{2}{*}{$\begin{array}{l}\text { Dental Faculty, } \\
\text { University of } \\
\text { Granada, Spain }\end{array}$} & \multirow{2}{*}{$\begin{array}{c}\text { Papaya leaf extract dentifrice/mouthwash provides } \\
\text { an efficacious and natural alternative to sodium } \\
\text { lauryl sulfate-free dentifrice and reduces } \\
\text { gingival bleeding. }\end{array}$} & \multirow[b]{2}{*}{ [161] } \\
\hline & $\begin{array}{l}\text { Application: } \\
\text { Mouthwash and tooth } \\
\text { paste }\end{array}$ & & & & \\
\hline \multirow{2}{*}{$\begin{array}{l}\text { Use of an antiviral mouthwash as a barrier measure in the } \\
\text { severe acute respiratory syndrome coronavirus } 2 \text { (SARS-CoV-2) } \\
\text { transmission in adults with asymptomatic to mild COVID-19: a } \\
\text { multicenter, randomized, double-blind controlled trial }\end{array}$} & $\begin{array}{l}\text { B-cyclodextrin and } \\
\text { citrox (bioflavonoids) } \\
\text { (CDCM) }\end{array}$ & \multirow{2}{*}{$\begin{array}{l}\text { To determine if commercially available mouthwash with } \\
\text { CDCM could decrease the SARS-CoV-2 load from saliva }\end{array}$} & \multirow{2}{*}{$\begin{array}{l}\text { Hospital Centers, } \\
\text { France }\end{array}$} & \multirow{2}{*}{$\begin{array}{l}\text { CDCM had a significant beneficial effect on } \\
\text { reducing SARS-CoV-2 salivary viral load in } 280 \\
\text { adults with asymptomatic or mild COVID-19, } 4 \mathrm{~h} \\
\text { after the initial dose. }\end{array}$} & \multirow{2}{*}{ [162] } \\
\hline & $\begin{array}{l}\text { Application: } \\
\text { Mouthwash }\end{array}$ & & & & \\
\hline
\end{tabular}




\section{Conclusions}

According to the evidence presented in this review, EOs have the potential to be used as preventive or therapeutic agents for a variety of oral diseases. Despite the fact that many other potential uses of EOs have been identified and many reports of therapeutic efficacy have been adequately validated by either in vitro testing or in vivo clinical trials, more research is needed to determine the safety and efficacy of these EOs before they are used in clinical practice. They can be very useful in dental therapy and contribute to improving the quality of dental treatments if used properly. Clinical studies that validate the therapeutic potential of EOs in vivo and discuss concerns including adverse effects, toxicity, and their interaction with other drug molecules, in particular, would be extremely beneficial. Based on the available data, it can be concluded that EOs have the potential to be developed as preventative or therapeutic agents for a variety of oral diseases, but further clinical trials are needed to confirm their safety and efficacy. There is strong evidence that plant extracts, essential oils, and extracted plant chemicals have the ability to evolve into treatments that can be used as curative agents for oral diseases, as shown by various examples included in this review. While the number of clinical trials for such drugs is promising, more research on their effectiveness would be needed to determine their therapeutic effects, either alone or in conjunction with traditional therapies. The review addresses the research issues of standardization of extracts or purified compounds, and quality control would be of great significance to obtain better dental care with the support of accessible natural wealth. This review gives an outline of essential oils, their therapeutic belongings, and their effects.

Author Contributions: Conceptualization: M.K., M.M., Radha, N.K., and S.P. (Suraj Prakash); writing-original draft preparation: S.P. (Sneh Punia), A.P., P.C., S.C., O.A., S.D., T.I., P.C.P., and S.S. (Surinder Singh); writing-review and editing: S.S. (Sudha Singh), N.S., M.K., R., S.P., V.S., and M.M. All authors have read and agreed to the published version of the manuscript.

Funding: This research received no external funding.

Acknowledgments: The authors would like to thank the University of Kiel and Schleswig-Holstein for their support through the OA program.

Conflicts of Interest: The authors declare no conflict of interest.

\section{References}

1. James, S.L.; Abate, D.; Abate, K.H.; Abay, S.M.; Abbafati, C.; Abbasi, N.; Abbastabar, H.; Abd-Allah, F.; Abdela, J.; Abdelalim, A.; et al. Global, regional, and national incidence, prevalence, and years lived with disability for 354 Diseases and Injuries for 195 countries and territories, 1990-2017: A systematic analysis for the Global Burden of Disease Study 2017. Lancet 2018, 392, 1789-1858. [CrossRef]

2. Petti, S.; Glendor, U.; Andersson, L. World traumatic dental injury prevalence and incidence, a meta-analysis-One billion living people have had traumatic dental injuries. Dent. Traumatol. 2018, 34, 71-86. [CrossRef]

3. Agbor, M.A.; Naidoo, S. Ethnomedicinal plants used by traditional healers to treat oral health problems in Cameroon. Evid.-Based Complement. Altern. Med. 2015, 2015, 649832. [CrossRef] [PubMed]

4. Şener, B.; Kiliç, M. Herbal extracts used in dental disorders. J. Sci. Tech. Res. 2019, 19, 14107-14111. [CrossRef]

5. Martínez, C.C.; Gómez, M.D.; Oh, M.S. Use of traditional herbal medicine as an alternative in dental treatment in mexican dentistry: A review. Pharm. Biol. 2017, 55, 1992-1998. [CrossRef]

6. Baratta, M.T.; Dorman, H.J.D.; Deans, S.G.; Figueiredo, A.C.; Barroso, J.G.; Ruberto, G. Antimicrobial and antioxidant properties of some commercial essential oils. Flavour Fragr. J. 1998, 13, 235-244. [CrossRef]

7. Hammer, K.A.; Carson, C.F.; Riley, T.V. Antimicrobial activity of essential oils and other plant extracts. J. Appl. Microbiol. 1999, 86, 985-990. [CrossRef]

8. Guleria, S.; Tiku, A.K.; Koul, A.; Gupta, S.; Singh, G.; Razdan, V.K. Antioxidant and Antimicrobial Properties of the Essential Oil and Extracts of Zanthoxylum alatum Grown in North-Western Himalaya. Sci. World J. 2013, 2013, 790580. [CrossRef]

9. Thosar, N.; Basak, S.; Bahadure, R.N.; Rajurkar, M. Antimicrobial efficacy of five essential oils against oral pathogens: An in vitro study. Eur. J. Dent. 2013, 7, S071-S077. [CrossRef] [PubMed]

10. Nordin, A.; Saim, A.B.; Ramli, R.; Hamid, A.A.; Nasri, N.W.M.; Idrus, R.B.H. Miswak and oral health: An evidence-based review. Saudi J. Biol. Sci. 2020, 27, 1801-1810. [CrossRef]

11. Agarwal, R.; Lakshmi, T. Eucalyptus oil in dentistry: A mini Review. Int. J. Drug Dev. Res. 2013, 5, 58-61. 
12. Fani, M.; Kohanteb, J. In Vitro Antimicrobial Activity of Thymus vulgaris Essential Oil against Major Oral Pathogens. J. Evid.-Based Complement. Altern. Med. 2017, 22, 660-666. [CrossRef]

13. Jenkinson, H.F.; Lamont, R.J. Oral microbial communities in sickness and in health. Trends Microbiol. 2005, 13, 589-595. [CrossRef]

14. Tichy, J.; Novak, J. Extraction, assay, and analysis of antimicrobials from plants with activity against dental pathogens (Streptococcus sp.). J. Altern. Complement. Med. 1998, 4, 39-45. [CrossRef]

15. Badria, F.A.; Zidan, O.A. Natural products for dental caries prevention. J. Med. Food 2004, 7, 381-384. [CrossRef] [PubMed]

16. Kurose, K.; Yatagai, M. Components of the essential oils of Azadirachta indica A. Juss, Azadirachta siamensis Velton, and Azadirachta excelsa (Jack) Jacobs and their comparison. J. Wood Sci. 2005, 51, 185-188. [CrossRef]

17. Alok, S.; Jain, S.K.; Verma, A.; Kumar, M.; Mahor, A.; Sabharwal, M. Plant profile, phytochemistry and pharmacology of Asparagus racemosus (Shatavari): A review. Asian Pac. J. Trop. Dis. 2013, 3, 242-251. [CrossRef]

18. Dash, T.R.; Singh, N.; Gupta, D.; Panwar, E.; Ramisetty, S. Role of medicinal herbs in oral health management. J. Int. Dent. Med. Res. 2014, 1, 113-119.

19. Rajput, S.B.; Tonge, M.B.; Karuppayil, S.M. An overview on traditional uses and pharmacological profile of Acorus calamus Linn. (Sweet flag) and other Acorus species. Phytomedicine 2014, 21, 268-276. [CrossRef]

20. Al-Asmari, A.K.; Athar, M.T.; Al-Faraidy, A.A.; Almuhaiza, M.S. Chemical composition of essential oil of Thymus vulgaris collected from Saudi Arabian market. Asian Pac. J. Trop. Biomed. 2017, 7, 147-150. [CrossRef]

21. Verma, G.; Sharma, V. A scientific update on Juglans regia Linn. Asian J. Pharm. Res. Dev. 2020, 8, 166-175. [CrossRef]

22. Prabu, G.R.; Gnanamani, A.; Sadulla, S. Guaijaverin-A plant flavonoid as potential antiplaque agent against Streptococcus mutans. J. Appl. Microbiol. 2006, 101, 487-495. [CrossRef]

23. Bhattacharjee, A.; Kumar, B.D.; Das, B.; Dkhar, D.; Kachari, D. Zanthoxylum Armatum: A systemic review of its ethno-medicinal properties, phytochemistry, pharmacology and toxicology. Adv. Pharmacol. Clin. Trials 2019, 4, 000162. [CrossRef]

24. Negi, J.S.; Bisht, V.K.; Bhandari, A.K.; Bisht, R.; Negi, S.K. Major constituents, antioxidant and antibacterial activities of Zanthoxylum armatum DC. essential oil. Iran. J. Pharmacol. Ther. 2012, 11, 68-72.

25. Mehta, D.K.; Das, R.; Bhandari, A. In-vitro anthelmintic activity of seeds of Zanthoxylum armatum DC. against Pheretima Posthuma. Int. J. Green Pharm. 2012, 6. [CrossRef]

26. Smitha, G.R.; Varghese, T.S.; Manivel, P. Cultivation of Ocimum. Ext. Bull. Dir. Med. Aromat. Plants Res. Anand, Gujarat, India 2014, 30 .

27. Iqbal, Z.; Akhtar, M.; Sabri, M.U.; Altaf, A. Chemical composition of ocimum sanctum essential oil by GC-MS analysis. Nat. Prod. Chem. Res. 2020, 8, 1-5. [CrossRef]

28. Annigeri, R.G.; Mangala, G.K.; Thimmasetty, J.; Sharma, N.; Kanjani, V.; Sravya, G. Evaluation of tulasi extract mouthwash in the management of oral candidiasis. J. Adv. Clin. Res. Insights 2018, 5, 30-34. [CrossRef]

29. Saftarasmi; Lakshmi, T. Ocimum Sanctum in Dental Care-A Mini Review. Res. J. Pharm. Technol. 2014, 7, $101-103$.

30. Khatak, M.; Khatak, S.; Siddqui, A.; Vasudeva, N.; Aggarwal, A.; Aggarwal, P. Salvadora persica. Pharmacogn. Rev. 2010, 4, 209-214. [CrossRef]

31. Alali, F.; Hudaib, M.; Aburjai, T.; Khairallah, K.; Al-Hadidi, N. GC-MS Analysis and Antimicrobial Activity of the Essential Oil from the Stem of the Jordanian Toothbrush Tree Salvadora persica. Pharm. Biol. 2005, 42, 577-580. [CrossRef]

32. Al-Dabbagh, S.A.; Qasim, H.J.; Al-Derzi, N.A. Efficacy of Miswak toothpaste and mouthwash on cariogenic bacteria. Saudi Med. J. 2016, 37, 1009-1014. [CrossRef] [PubMed]

33. Mbuya, L.P.; Msanga, H.P.; Ruffo, C.K.; Birnie, A.; Tengnäs, B. Useful Trees and Shrubs for Tanzania: Identification, Propagation and Management for Agricultural and Pastoral Communities; Regional Soil Conservation Unit, Swedish International Development Authority: Nairobi, Kenya, 1994.

34. Joshi, A.; Sharma, A.; Bachheti, R.K.; Pandey, D.P. A comparative study of the chemical composition of the essential oil from Eucalyptus globulus growing in Dehradun (India) and around the world. Orient. J. Chem. 2016, 32, 331-340. [CrossRef]

35. Ragul, P.; Dhanraj, M.; Jain, A.R. Efficacy of eucalyptus oil over chlorhexidine mouthwash in dental practice in dental practice. Drug Invent. Today 2018, 10, 638-641.

36. Reddy, V.P.; Kandisa, R.V.; Varsha, P.V.; Satyam, S. Review on Thymus vulgaris Traditional Uses and Pharmacological Properties. Med. Aromat. Plants 2014, 3, 164. [CrossRef]

37. Santos, R.I.; Pereira, D.F.; Teodoro, G.R.; Del Ciampo, J.O.; Ogasawara, M.S.; Canettieri, A.C.; Salvador, M.J. Essential oil of Thymus vulgaris: Preparation of pharmaceutical mouthwash formulation and In Vitro evaluation of the bacterial plaque-inhibiting properties. Lat. Am. J. Pharm. 2010, 29, 941-947.

38. Teklay, A.; Abera, B.; Giday, M. An ethnobotanical study of medicinal plants used in kilte awulaelo district, tigray region of ethiopia. J. Ethnobiol. Ethnomed. 2013, 9, 65. [CrossRef] [PubMed]

39. Tewari, D.N. Monograph on Neem (Azadirachta Indica A. Juss.); International Book Distributors: Dehradun, India, 1992.

40. Malik, A.; Shaukat, M.; Qureshi, A.; Abdur, R. Comparative effectiveness of chewing stick and toothbrush: A randomized clinical trial. N. Am. J. Med. Sci. 2014, 6, 333. [CrossRef]

41. Kaushik, A.; Kaushik, M.; Tanwar, R. Ethnomedicine: Applications of Neem (Azadirachta indica) in dentistry. Dent. Hypotheses 2012, 3, 112. [CrossRef]

42. Chandra, D.; Prasad, K.; Kohli, G.; Bisht, G.; Punetha, V.D.; Khetwal, K.S.; Pandey, H.K. Essential oil composition of Acorus calamus from District-Pithoragarh, Uttarakhad, India. World J. Pharm. Res. 2015, 4, 1158-1166. 
43. Nanda, B.L.; Sultana, S.N.; Radhakrishnan, T.T. Determination of phytochemicals and antioxidant activity of Acorus calamus rhizome. J. Drug Deliv. Ther. 2014, 4, 117-121. [CrossRef]

44. Rao, N.S.B.; Rajasekhar, D.; Raju, D.C.; Nagaraju, N. Ethno-medicinal notes on some plants of Tirumala hills for dental disorders. Ethnobotany 1996, 8, 88-91.

45. Abdallah, I.B.; Baatour, O.; Mechrgui, K.; Herchi, W.; Albouchi, A.; Chalghoum, A.; Boukhchina, S. Essential oil composition of walnut tree (Juglans regia L.) leaves from Tunisia. J. Essent. Oil Res. 2016, 28, 545-550. [CrossRef]

46. Saimbi, C.S.; Shubh, N.; Kapoor, K.K.; Kaushal, S. Clinical effect of Juglans regia on developing dental plaque. J. Int. Clin. Dent. Res. Organ. 2009, 1, 4 .

47. Gyawali, R.; Kim, K.-S. Bioactive volatile compounds of three medicinal plants from Nepal. Kathmandu Univ. J. Sci. Eng. Technol. 2012, 8, 51-62. [CrossRef]

48. Singla, R.; Jaitak, V. Shatavari (Asparagus racemosus Wild): A review on its cultivation, morphology, phytochemistry and pharmacological importance. Int. J. Pharm. Sci. Res. 2014, 5, 742-757. [CrossRef]

49. Karuna, D.S.; Dey, P.; Das, S.; Kundu, A.; Bhakta, T. In vitro antioxidant activities of root extract of Asparagus racemosus Linn. J. Tradit. Complement. Med. 2018, 8, 60-65. [CrossRef]

50. Vani, S.K.; Sivakumar, G.; Geetha, R.V.; Priya, V.V. Evaluation of antibacterial activity of Asparagus racemosus extract-An in vitro study. Drug Invent. Today 2019, 11, 971-973.

51. Shah, G.; Baghel, U.S. Melaleuca alternifolia: A review of the medicinal uses, pharmacology and phytochemistry. Int. J. ChemTech Res. 2017, 10, 418-427.

52. Carson, C.F.; Hammer, K.A.; Riley, T.V. Melaleuca alternifolia (tea tree) oil: A review of antimicrobial and other medicinal properties. Clin. Microbiol. Rev. 2006, 19, 50-62. [CrossRef]

53. Piekarz, T.; Mertas, A.; Wiatrak, K.; Rój, R.; Kownacki, P.; Śmieszek-Wilczewska, J.; Kopczyńska, E.; Wrzoł, M.; Cisowska, M.; Szliszka, E.; et al. The influence of toothpaste containing australian Melaleuca alternifolia oil and ethanolic extract of polish propolis on oral hygiene and microbiome in patients requiring conservative procedures. Molecules 2017, 22, 1957. [CrossRef]

54. Elgendy, E.A.; Abdel-Moula Ali, S.; Zineldeen, D.H. Effect of local application of tea tree (Melaleuca alternifolia) oil gel on long pentraxin level used as an adjunctive treatment of chronic periodontitis: A randomized controlled clinical study. J. Indian Soc. Periodontol. 2013, 17, 444-448. [CrossRef] [PubMed]

55. Casarin, M.; Pazinatto, J.; Santos, R.C.V.; Zanatta, F.B. Melaleuca alternifolia and its application against dental plaque and periodontal diseases: A systematic review. Phyther. Res. 2018, 32, 230-242. [CrossRef] [PubMed]

56. Rajvaidhya, S.; Nagori, B.P.; Singh, G.K.; Dubey, B.K.; Desai, P.; Jain, S. A review on Acacia arabica-an Indian medicinal plant. Int. J. Pharm. Sci. Res. 2012, 3, 1995-2005. [CrossRef]

57. Ogunbinu, A.O.; Okeniyi, S.; Flamini, G.; Cioni, P.L.; Ogunwande, I.A.; Babalola, I.T. Essential oil composition of Acacia nilotica linn., and Acacia albida delile (Leguminosae) from Nigeria. J. Essent. Oil Res. 2010, 22, 540-542. [CrossRef]

58. Badshah, L.; Hussain, F. People preferences and use of local medicinal flora in District Tank, Pakistan. J. Med. Plants Res. 2011, 5, 22-29.

59. Pote, M.; Hirapure, P. Antimicrobial potential of Acacia nilotica extracts on few dental pathogens. Int. J. Pharm. Sci. Res. 2014, 5, 4759. [CrossRef]

60. Saeedi, R.; Sultana, A.; Rahman, K. Medicinal properties of different parts of Acacia nilotica Linn. (babul), its phytoconstituents and diverse pharmacological activities. Int. J. Pharm. Pharm. Sci. 2020, 12, 8-14. [CrossRef]

61. Shariatifar, N.; Fathabad, A.E.; Khaniki, G.J.; Nasrabadi, H.G. Evaluation of the antibacterial activity of essential oil and aqueous and ethanolic extracts of Quercus infectoria leaves on food-borne pathogenic bacteria. Int. J. Pharma Sci. Res. 2014, 5, 709-713.

62. Basri, D.F.; Tan, L.S.; Shafiei, Z.; Zin, N.M. In vitro antibacterial activity of galls of Quercus infectoria Olivier against oral pathogens. Evid.-Based Complement. Altern. Med. 2012, 2012, 632796. [CrossRef]

63. Sharopov, F.S.; Salimov, A.; Numonov, S.; Bakri, M.; Sangov, Z.; Habasi, M.; Aisa, H.A.; Setzer, W.N. Phytochemical study on the essential oils of Tarragon (Artemisia dracunculus L.) growing in Tajikistan and its comparison with the essential oil of the species in the rest of the world. Nat. Prod. Commun. 2020, 15, 1934578X20977394. [CrossRef]

64. Raeisi, M.; Tajik, H.; Razavi roohani, S.M.; Maham, M.; Moradi, M.; Hajimohammadi, B.; Naghili, H.; Hashemi, M.; Mehdizadeh, T. Essential oil of tarragon (Artemisia dracunculus) antibacterial activity on Staphylococcus aureus and Escherichia coli in culture media and Iranian white cheese. Iran. J. Microbiol. 2012, 4, 30-33. [PubMed]

65. Wongkham, S.; Taweechaisupapong, S. Koi: Medicinal plant for oral hygiene. Thai J. Pharmacol. 2005, 27, 137-145.

66. Phutdhawong, W.; Donchai, A.; Korth, J.; Pyne, S.G.; Picha, P.; Ngamkham, J.; Buddhasukh, D. The components and anticancer activity of the volatile oil fromStreblus asper. Flavour Fragr. J. 2004, 19, 445-447. [CrossRef]

67. Kumar, G.; Kanungo, S.; Panigrahi, K. Pharmacology \& Clinical Research Antimicrobial Effects of Streblus Asper Leaf Extract: A Randomized Controlled Clinical Trial. J. Pharmacol. Clin. Res. 2020, 8. [CrossRef]

68. Pope, G.V. Notes on Vernonieae (Compositae) in the Flora Zambesiaca Area. Kew Bull. 1990, 45, 697. [CrossRef]

69. Haghi, G.; Arshi, R.; Ghazian, F.; Hosseini, H. Chemical composition of essential oil of aerial parts of Cichorium intybus L. from iran. J. Essent. Oil-Bear. Plants 2012, 15, 213-216. [CrossRef]

70. Al-Snafi, A.E. Medical importance of Cichorium intybus-A review. IOSR J. Pharm. 2016, 6, 41-56.

71. Street, R.A.; Sidana, J.; Prinsloo, G. Cichorium intybus: Traditional Uses, Phytochemistry, Pharmacology, and Toxicology. Evid.-Based Complement. Altern. Med. 2013, 2013, 579319. [CrossRef] 
72. Venkateswarlu, K. Vitex negundo: Medicinal values, biological activities, toxicity studies and phytopharmacological actions. Int. J. Pharm. Phytopharm. Res. 2012, 2, 126-133.

73. Singh, A.; Sharma, P.K.; Garg, V.K.; Visht, S. Extraction and analysis of essential oil of Nirgundi (Vitex negundo L.). Der Pharm. Sin. 2011, 2, 262-266.

74. Suganthi, N.; Dubey, S. Phytochemical constituents and pharmacological activities of Vitex negundo Linn. J. Chem. Pharm. Res. 2016, 8, 800-807.

75. Sanjay, N.; Tiwari, M.M. Antibacterial activity of Nirgundi (Vitex negundo Linn.). Environ. Conserv. J. 2007, 8, 31-33.

76. Maurya, H.; Rao, V. Article 1007 The Favorable Role of Alkaloids from Vitex negundo in the Management of Human Ailments. Ann. Clin. Pharmacol. Toxicol. 2019, 1, 1007.

77. Begum, A.; Sandhya, S.; Ali, S.S.; Vinod, K.R.; Reddy, S.; Banji, D. An in-depth review on the medicinal flora Rosmarinus officinalis (Lamiaceae). Acta Sci. Pol. Technol. Aliment. 2013, 12, 61-73.

78. de Macedo, L.M.; dos Santos, É.M.; Militão, L.; Tundisi, L.L.; Ataide, J.A.; Souto, E.B.; Mazzola, P.G. Rosemary (Rosmarinus officinalis L., syn Salvia rosmarinus Spenn.) and Its Topical Applications: A Review. Plants 2020, 9, 651. [CrossRef] [PubMed]

79. de Oliveira, J.R.; Camargo, S.E.A.; de Oliveira, L.D. Rosmarinus officinalis L. (rosemary) as therapeutic and prophylactic agent. J. Biomed. Sci. 2019, 26, 1-22. [CrossRef] [PubMed]

80. Valones, M.A.A.; Silva, I.C.G.; Gueiros, L.A.M.; Leão, J.C.; Caldas, A.F.; Carvalho, A.A.T. Clinical assessment of rosemarybased toothpaste (Rosmarinus officinalis linn.): A randomized controlled double-blind study. Braz. Dent. J. 2019, 30, 146-151. [CrossRef]

81. Shankar, R.; Lavekar, G.S.; Deb, S.; Sharma, B.K.; Rawat, M.S. Distribution, conservation and folk uses of Vaibidang (Embelia ribes Burm. f.). Int. J. Biodivers. Conserv. 2012, 4, 525-529. [CrossRef]

82. Radhakrishnan, N.; Gnanamani, A.; Mandal, A.B. A potential antibacterial agent Embelin, a natural benzoquinone extracted from Embelia ribes. Biol. Med. 2011, 3, 1-7.

83. Radhakrishnan, N.; Gnanamani, A. 2, 5-dihydroxy-3-undecyl-1, 4-benzoquinone (embelin)-A second solid gold of India-A review. Int. J. Pharm. Pharm. Sci. 2014, 6, 2014.

84. Lal, B.; Mishra, N. Importance of Embelia ribes: An update. Int. J. Pharm. Sci. Res. 2013, 4, 3823. [CrossRef]

85. Asadulla, S.; Ramandang, R. Pharmacognosy of Embelia ribes Burm. f. Int. J. Res. Pharm. Chem. 2011, 1, $1236-1251$.

86. Paulraj, J.; Govindarajan, R.; Palpu, P. The Genus Spilanthes Ethnopharmacology, Phytochemistry, and Pharmacological Properties: A Review. Adv. Pharmacol. Sci. 2013, 2013, 510298. [CrossRef]

87. Srinath, J.; Laksmi, T. Therapeutic potential of Spilanthes acmella-A dental note. Int. J. Pharm. Sci. Res. 2014, 25, 151-153.

88. Chadha, M.L. Indigenous vegetables of India with potentials for improving livelihood. Acta Hortic. 2009, 806, 579-586. [CrossRef]

89. Nakatani, N.; Nagashima, M. Pungent Alkamides from Spilanthes acmella L. var. oleracea Clarke. Biosci. Biotechnol. Biochem. 1992, 56, 759-762. [CrossRef]

90. Noumi, E.; Dibakto, T.W. Medicinal plants used for peptic ulcer in the Bangangte region, western Cameroon. Fitoterapia 2000, 71, 406-412. [CrossRef]

91. Chopra, R.N.; Nayar, S.L.; Chopra, I.C. Glossary of Indian Medicinal Plants. Q. Rev. Biol. 1958, 33, 156. [CrossRef]

92. Kala, C.P. Ethnomedicinal botany of the Apatani in the Eastern Himalayan region of India. J. Ethnobiol. Ethnomed. $2005,1,11$. [CrossRef] [PubMed]

93. Datta, A.K.; Datta, A.K.; Saha, A.; Bhattacharya, A.; Mandal, A.; Paul, R.; Sengupta, S. Black cumin (Nigella sativa L.)-a review Comperative assessment of immediate and heritable effect of nanoparticles and conventional mutagen. View project black cumin (Nigella sativa L.)-A review. J. Plant Dev. Sci. 2012, 4, 1-43.

94. Ghahramanloo, K.H.; Kamalidehghan, B.; Akbari Javar, H.; Teguh Widodo, R.; Majidzadeh, K.; Noordin, M.I. Comparative analysis of essential oil composition of iranian and indian Nigella sativa L. Extracted using supercritical fluid extraction and solvent extraction. Drug Des. Devel. Ther. 2017, 11, 2221-2226. [CrossRef]

95. Mekhemar, M.; Hassan, Y.; Dörfer, C. Nigella sativa and thymoquinone: A natural blessing for periodontal therapy. Antioxidants 2020, 9, 1260. [CrossRef]

96. Nordin, A.; Kamal, H.; Yazid, M.D.; Saim, A.; Idrus, R. Effect of Nigella sativa and its bioactive compound on type 2 epithelial to mesenchymal transition: A systematic review. BMC Complement. Altern. Med. 2019, 19, 290. [CrossRef]

97. Rivera, D.; Allkin, R.; Obón, C.; Alcaraz, F.; Verpoorte, R.; Heinrich, M. What is in a name? the need for accurate scientific nomenclature for plants. J. Ethnopharmacol. 2014, 152, 393-402. [CrossRef]

98. Page, M.J.; McKenzie, J.E.; Bossuyt, P.M.; Boutron, I.; Hoffmann, T.C.; Mulrow, C.D.; Shamseer, L.; Tetzlaff, J.M.; Akl, E.A.; Brennan, S.E.; et al. The PRISMA 2020 statement: An updated guideline for reporting systematic reviews. Syst. Rev. 2021, 10, 1-11. [CrossRef] [PubMed]

99. Gewali, M.B.; Awale, S. Aspects of Traditional Medicine in Nepal; University of Toyama: Toyama, Japan, 2008.

100. Patino, L.O.J.; Prieto, R.J.A.; Cuc, S.L.E. Zanthoxylum Genus as Potential Source of Bioactive Compounds. In Bioactive Compounds in Phytomedicine; InTech: London, UK, 2012.

101. Ocheng, F.; Bwanga, F.; Joloba, M.; Borg-Karlson, A.K.; Gustafsson, A.; Obua, C. Antibacterial activities of extracts from Ugandan medicinal plants used for oral care. J. Ethnopharmacol. 2014, 155, 852-855. [CrossRef]

102. Wang, H.; Ren, D. Controlling Streptococcus mutans and Staphylococcus aureus biofilms with direct current and chlorhexidine. AMB Express 2017, 7, 204. [CrossRef] 
103. Mukhtar, H.M.; Kalsi, V. A review on medicinal properties of zanthoxylum armatum DC. Res. J. Pharm. Technol. 2018, 11, 2131-2138. [CrossRef]

104. Tsunozaki, M.; Lennertz, R.C.; Vilceanu, D.; Katta, S.; Stucky, C.L.; Bautista, D.M. A “toothache tree" alkylamide inhibits A $\delta$ mechanonociceptors to alleviate mechanical pain. J. Physiol. 2013, 591, 3325-3340. [CrossRef] [PubMed]

105. Kalra, K.; Vasthare, R.; Shenoy, P.A.; Vishwanath, S.; Singhal, D.K. Antibacterial efficacy of essential oil of two different varieties of ocimum (tulsi) on oral microbiota-an invitro study. Indian J. Public Health Res. Dev. 2019, 10, 188-193. [CrossRef]

106. Prakash, P.; Gupta, N. Therapeutic uses of Ocimum sanctum Linn (Tulsi) with a note on eugenol and its pharmacological actions: A short review. Indian J. Physiol. Pharmacol. 2005, 49, 125-131.

107. Frisch, J.; Bhaskar, S.N. Tissue Response to Eugenol-containing Periodontal Dressings. J. Periodontol. 1967, 38, 402-408. [CrossRef] [PubMed]

108. Khan, A.; Ahmad, A.; Manzoor, N.; Khan, L.A. Antifungal Activities of Ocimum sanctum Essential Oil and its Lead Molecules. Nat. Prod. Commun. 2010, 5, 1934578X1000500235. [CrossRef]

109. Agarwal, P.; Nagesh, L. Murlikrishnan Evaluation of the antimicrobial activity of various concentrations of Tulsi (Ocimum sanctum) extract against Streptococcus mutans: An in vitro study. Indian J. Dent. Res. 2010, 21, 357-359. [CrossRef]

110. Kamal, S.A.; Hameed, I.H.; Mohammed, G.J. Antimicrobial, Anti-inflammatory, Analgesic Potential and Cytotoxic Activity of Salvadora persica: A Review. Artic. Indian J. Public Health Res. Dev. 2018, 9, 393-398. [CrossRef]

111. Abhary, M.; Al-Hazmi, A.A. Antibacterial activity of Miswak (Salvadora persica L.) extracts on oral hygiene. J. Taibah Univ. Sci. 2016, 10, 513-520. [CrossRef]

112. Khan, M.; Alkhathlan, H.Z.; Khan, S.T. Antibiotic and antibiofilm activities of Salvadora persica L. Essential oils against Streptococcus mutans: A detailed comparative study with chlorhexidine digluconate. Pathogens 2020, 9, 66. [CrossRef] [PubMed]

113. Palanna, R.M. Eucalyptus in India, Conservator of Forests, Kanara Circle, Karnataka, India. Available online: http://www.fao org/3/AC772E/ac772e06.htm (accessed on 1 May 2021).

114. Mayaud, L.; Carricajo, A.; Zhiri, A.; Aubert, G. Comparison of bacteriostatic and bactericidal activity of 13 essential oils against strains with varying sensitivity to antibiotics. Lett. Appl. Microbiol. 2008, 47, 167-173. [CrossRef] [PubMed]

115. Bachir, R.G.; Benali, M. Antibacterial activity of the essential oils from the leaves of Eucalyptus globulus against Escherichia coli and Staphylococcus aureus. Asian Pac. J. Trop. Biomed. 2012, 2, 739-742. [CrossRef]

116. Gonçalves, G.M.S.; Bottaro, M.; Nilson, A.C. Effect of the Thymus vulgaris essential oil on the growth of Streptococcus mutans. J. Basic Appl. Pharm. Sci. Rev. Ciênc Farm. Básica Apl 2011, 32, 375-380.

117. Champion, S.H.; Seth, S.K.; Khattak, G.M. Manual of silviculture for Pakistan. Man. Silvic. 1965, 523-543.

118. Webb, D.B.; Wood, P.J.; Smith, J.P.; Henman, G.S. A Guide to Species Selection for Tropical and Sub-Tropical Plantations; University of Oxford: Oxford, UK, 1984.

119. Vennila, K.; Naziya, K.; Elavarasu, S.; Abinaya, P.; Elanchezhiyan, S. Thangakumaran Evaluation of anti-plaque microbial activity of Azadirachta indica (neem oil) in vitro: A pilot study. J. Pharm. Bioallied Sci. 2012, 4, 394. [CrossRef] [PubMed]

120. Lakshmi, T.; Krishnan, V.; Rajendran, R.; Madhusudhanan, N. Azadirachta indica: A herbal panacea in dentistry-An update. Pharmacogn. Rev. 2015, 9, 41-44. [CrossRef] [PubMed]

121. Babatunde, D.E.; Otusemade, G.O.; Efeovbokhan, V.E.; Ojewumi, M.E.; Bolade, O.P.; Owoeye, T.F. Chemical composition of steam and solvent crude oil extracts from Azadirachta indica leaves. Chem. Data Collect. 2019, 20, 100208. [CrossRef]

122. Umamaheshwari, N.; Rekha, A. Sweet flag: (Acarus calamus)-An incredible medicinal herb. J. Pharmacogn. Phytochem. 2018, 7, $15-22$.

123. Shetty, R.N.; Shetty, S.B.; Janardhanan, S.; Shetty, S.; Shetty, S.; Raj, K. Comparative evaluation of effect of use of toothbrush with paste and munident on levels of Streptococcus mutans and gingival health in children: An in vivo study. J. Indian Soc. Pedod. Prev. Dent. 2017, 35, 162-166. [CrossRef]

124. Deshpande, R.R.; Kale, A.A.; Ruikar, A.D.; Panvalkar, P.S.; Kulkarni, A.A.; Deshpande, N.R.; Salvekar, J.P. Antimicrobial activity of different extracts of Juglans regia L. against oral microflora. Int. J. Pharm. Pharm. Sci. 2011, 3, $200-201$.

125. Zakavi, F.; Golpasand Hagh, L.; Daraeighadikolaei, A.; Farajzadeh Sheikh, A.; Daraeighadikolaei, A.; Leilavi Shooshtari, Z. Antibacterial effect of Juglans regia bark against oral pathologic bacteria. Int. J. Dent. 2013, 2013, 854765. [CrossRef]

126. Carrol, D.H.; Chassagne, F.; Dettweiler, M.; Quave, C.L. Antibacterial activity of plant species used for oral health against Porphyromonas gingivalis. PLoS ONE 2020, 15, e0239316. [CrossRef]

127. Nancy, P.; Manasi, M.; Varghese, A. Antiplaque activity of Juglans regia L. and characterization of Juglone from Juglans regia L. Am. J. Biochem. Biotechnol. 2011, 7, 29-31. [CrossRef]

128. Lohani, H.; Zafar, H.S.; Chauhan, N.K.; Mohan, C.M. Essential oil composition of leaves and berries of Juniperus communis and Juniperus indica from Uttarakhand Himalaya. J. Med. Aromat. Plant. Sci. 2010, 32, 199-201.

129. Megersa, M.; Jima, T.T.; Goro, K.K. The Use of Medicinal Plants for the Treatment of Toothache in Ethiopia. Evid.-Based Complement. Altern. Med. 2019, 2019, 2645174. [CrossRef]

130. Jiménez-Gayosso, S.I.; Lara-Carrillo, E.; Scougall-Vilchis, R.J.; Morales-Luckie, R.A.; Medina, S.C.E.; Velázquez-Enríquez, U.; Maupomé, G.; Herrera-Serna, B. Remineralizing effect of xilitol, Juniperus communis and Camellia sinensis added to a toothpaste: An in vitro study. Odovtos-Int. J. Dent. Sci. 2020, 22, 71-79. [CrossRef]

131. Zhilyakova, E.T.; Novikov, O.O.; Lysykh, E.G.; Zalivskaya, A. V Study of physical, chemical and consumer properties for development of dental gel basis aimed to cure of parodont diseases. J. Int. Pharm. Res. 2018, 45, 416-419. 
132. Raina, R.; Verma, P.K.; Peshin, R.; Kour, H. Potential of Juniperus communis L as a nutraceutical in human and veterinary medicine. Heliyon 2019, 5, e02376. [CrossRef]

133. Shah, G.; Baghel, U.S. Pharmacognostic standardization of the leaf of Melaleuca alternifolia (Maiden \& Betche) Cheel. Afr. J. Tradit. Complement. Altern. Med. AJTCAM 2017, 14, 1-11. [CrossRef]

134. Oliveira, T.R.; Teixeira, A.L.; Barbosa, J.P.; Busato de Feiria, S.N.; Boni, G.C.; Maia, F.; Anibal, P.C.; Wijesinghe, G.K.; Höfling, J.F. Melaleuca spp. essential oil and its medical applicability. A Brief Review. Braz. J. Nat. Sci. 2020, 3, 249. [CrossRef]

135. Brophy, J.J.; Davies, N.W.; Southwell, I.A.; Stiff, I.A.; Williams, L.R. Gas chromatographic quality control for oil of Melaleuca terpinen-4-ol type (Australian tea tree). J. Agric. Food Chem. 1989, 37, 1330-1335. [CrossRef]

136. Buck, D.S. Comparison of two topical preparations for the treatment of onyehornycosis: Melaleuca altemifilia (tea tree) oil and clotrimazole. J. Fam. Pract. 1994, 38, 601-605. [PubMed]

137. Banso A Phytochemical and antibacterial investigation of bark extracts of Acacia nilotica. J. Med. Plants Res. 2009, 3, 82-085.

138. Ikram, M.; Nowshad, F. Constituents of Quercus infectoria. Planta Med. 1977, 31, 286-287. [CrossRef]

139. Machado, T.B.; Pinto, A.V.; Pinto, M.C.F.R.; Leal, I.C.R.; Silva, M.G.; Amaral, A.C.F.; Kuster, R.M.; Netto-dosSantos, K.R. In vitro activity of Brazilian medicinal plants, naturally occurring naphthoquinones and their analogues, against methicillin-resistant Staphylococcus aureus. Int. J. Antimicrob. Agents 2003, 21, 279-284. [CrossRef]

140. Fogliani, B.; Raharivelomanana, P.; Bianchini, J.P.; Bouraïma-Madjèbi, S.; Hnawia, E. Bioactive ellagitannins from Cunonia macrophylla, an endemic Cunoniaceae from New Caledonia. Phytochemistry 2005, 66, 241-247. [CrossRef] [PubMed]

141. Hatano, T.; Kusuda, M.; Inada, K.; Ogawa, T.; Shiota, S.; Tsuchiya, T.; Yoshida, T. Effects of tannins and related polyphenols on methicillin-resistant Staphylococcus aureus. Phytochemistry 2005, 66, 2047-2055. [CrossRef]

142. Greenish, H.G. Materia Medica, 3rd ed.; Scientific Publisher: Jodhpur, India, 1999.

143. Ahmad, W.; Zeenat, F.; Hasan, A.; Abdullah, A.; Nargis, A.; Tarannum, T. Mazu (Quercus infectoria): An overview. Indian J. Unani Med. 2011, 4, 17-22.

144. Nigam, M.; Atanassova, M.; Mishra, A.P.; Pezzani, R.; Devkota, H.P.; Plygun, S.; Salehi, B.; Setzer, W.N.; Sharifi-Rad, J. Bioactive compounds and health benefits of Artemisia species. Nat. Prod. Commun. 2019, 14, 1934578X19850354.

145. Deans, S.G.; Simpson, E.J.M. Artemisia dracunculus. In Artemisia; Wright, C.W., Ed.; Taylor \& Francis Ltd.: London, UK; New York, NY, USA, 2001; pp. 91-97.

146. Wongkham, S.; Laupattarakasaem, P.; Pienthaweechai, K.; Areejitranusorn, P.; Wongkham, C.; Techanitiswad, T. Antimicrobial activity of Streblus asper leaf extract. Phyther. Res. 2001, 15, 119-121. [CrossRef]

147. Palombo, E.A. Traditional Medicinal Plant Extracts and Natural Products with Activity against Oral Bacteria: Potential Application in the Prevention and Treatment of Oral Diseases. Evid.-Based Complement. Altern. Med. 2011, 2011, 680354. [CrossRef] [PubMed]

148. Taweechaisupapong, S.; Klanrit, P.; Singhara, S.; Pitiphat, W.; Wongkham, S. Inhibitory effect of Streblus asper leaf-extract on adhesion of Candida albicans to denture acrylic. J. Ethnopharmacol. 2006, 106, 414-417. [CrossRef]

149. Saeed, M.; Abd El-Hack, M.E.; Alagawany, M.; Arain, M.A.; Arif, M.; Mirza, M.A.; Naveed, M.; Chao, S.; Sarwar, M.; Sayab, M.; et al. Chicory (Cichorium intybus) herb: Chemical composition, pharmacology, nutritional and healthical applications. Int. J. Pharmacol. 2017, 13, 351-360. [CrossRef]

150. Judžentienè, A.; Būdienè, J. Volatile constituents from aerial parts and roots of Cichorium intybus L. (chicory) grown in Lithuania. Chemija 2008, 19, 25-28.

151. Huang, H.C.; Chang, T.Y.; Chang, L.Z.; Wang, H.F.; Yih, K.H.; Hsieh, W.Y.; Chang, T.M. Inhibition of melanogenesis Versus antioxidant properties of essential oil extracted from leaves of Vitex negundo linn and chemical composition analysis by GC-MS. Molecules 2012, 17, 3902-3916. [CrossRef]

152. Ullah, Z.; Ullah, R.; Ahmad, I.; Haider, S. Phytochemical and Biological Evaluation of Vitex Negundo Linn: A Review. Int. J. Pharm. Sci. Res. 2012, 3, 2421-2431.

153. Patki; sunita amruthesh; Tandur; tandur; Malini Clinical evaluation of a novel herbal dental cream in plaque formation: A double-blind, randomized, controlled clinical trial. J. Exp. Pharmacol. 2010, 2010, 105. [CrossRef]

154. Simbo, D.J. An ethnobotanical survey of medicinal plants in Babungo, Northwest Region, Cameroon. J. Ethnobiol. Ethnomed. 2010, 6, 8. [CrossRef]

155. Tangjang, S.; Namsa, N.D.; Aran, C.; Litin, A. An ethnobotanical survey of medicinal plants in the Eastern Himalayan zone of Arunachal Pradesh, India. J. Ethnopharmacol. 2011, 134, 18-25. [CrossRef]

156. Nadar, B.; Usha, G.; Lakshminarayan, N. Comparative evaluation of efficacy of $4 \%$ tulsi extract (Ocimum sanctum), fluoridated and placebo dentifrices against gingivitis and plaque among 14-15 years school children in Davangere City, India-A triple blinded randomized clinical trial. Contemp. Clin. Dent. 2020, 11, 67-75. [CrossRef] [PubMed]

157. Malik, A. Comparative clinical effects of Salvadora persica oral rinse and a phenolic commercial mouth wash on human oral health; An Invivo randomized trial. J. Pak. Dent. Assoc. 2021, 30, 87-93. [CrossRef]

158. Sukhabogi, J.R.; Chandra Shekar, B.R.; Venkata Ramana, I.; Yadav, S.S.; Satish Kumar, G.; Harita, N. Antiplaque efficacy of tooth and gums tonic, Hiora-GA gel, and Spirogyl Gum Paint in comparison with chlorhexidine M gel: A double-blind randomized control trial. Contemp. Clin. Dent. 2017, 8, 42-47. [CrossRef] [PubMed]

159. Hosny, N.S.; El Khodary, S.A.; El Boghdadi, R.M.; Shaker, O.G. Effect of Neem (Azadirachta indica) versus $2.5 \%$ sodium hypochlorite as root canal irrigants on the intensity of post-operative pain and the amount of endotoxins in mandibular molars with necrotic pulps: A randomized controlled trial. Int. Endod. J.. [CrossRef] 
160. Taalab, M.R.; Mahmoud, S.A.; Moslemany, R.M.E.; Abdelaziz, D.M. Intrapocket application of tea tree oil gel in the treatment of stage 2 periodontitis. BMC Oral Health 2021, 21, 239. [CrossRef] [PubMed]

161. Saliasi, I.; Llodra, J.C.; Bravo, M.; Tramini, P.; Dussart, C.; Viennot, S.; Carrouel, F. Effect of a toothpaste/mouthwash containing carica papaya leaf extract on interdental gingival bleeding: A randomized controlled trial. Int. J. Environ. Res. Public Health 2018, 15, 2660. [CrossRef] [PubMed]

162. Carrouel, F.; Valette, M.; Gadea, E.; Esparcieux, A.; Illes, G.; Langlois, M.E.; Perrier, H.; Dussart, C.; Tramini, P.; Ribaud, M.; et al. Use of an antiviral mouthwash as a barrier measure in the SARS-CoV-2 transmission in adults with asymptomatic to mild COVID-19: A multicentre, randomized, double-blind controlled trial. Clin. Microbiol. Infect. 2021. [CrossRef] [PubMed] 